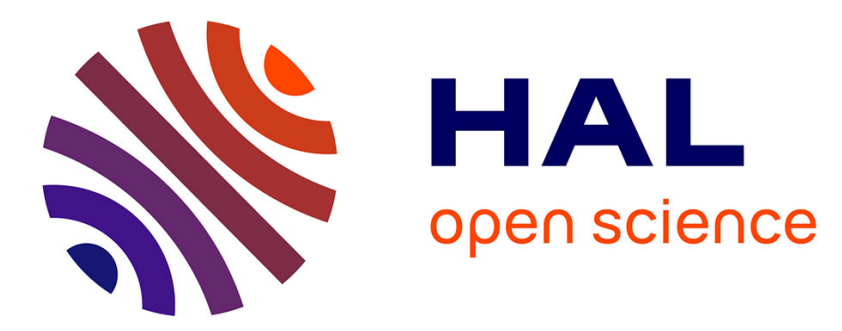

\title{
New data for the Early Upper Paleolithic of Kostenki (Russia)
}

Rob Dinnis, Alexander A Bessudnov, Natasha Reynolds, Thibaut Deviese, Abi Pate, Mikhail V Sablin, Andrei Sinitsyn, Thomas Higham

\section{- To cite this version:}

Rob Dinnis, Alexander A Bessudnov, Natasha Reynolds, Thibaut Deviese, Abi Pate, et al.. New data for the Early Upper Paleolithic of Kostenki (Russia). Journal of Human Evolution, 2019, 127, pp.21-40. 10.1016/j.jhevol.2018.11.012 . hal-01982049

\section{HAL Id: hal-01982049 https://hal.science/hal-01982049}

Submitted on 15 Jan 2019

HAL is a multi-disciplinary open access archive for the deposit and dissemination of scientific research documents, whether they are published or not. The documents may come from teaching and research institutions in France or abroad, or from public or private research centers.
L'archive ouverte pluridisciplinaire HAL, est destinée au dépôt et à la diffusion de documents scientifiques de niveau recherche, publiés ou non, émanant des établissements d'enseignement et de recherche français ou étrangers, des laboratoires publics ou privés. 
Post-print of article published in Journal of Human Evolution:

Dinnis, R., Bessudnov, A. A., Reynolds, N., Devièse, T., Pate, A., Sablin, M. V., Sinitsyn, A. A. \& Higham, T. 2019. New data for the Early Upper Paleolithic of Kostenki (Russia). Journal of Human Evolution 127: 21-40. https://doi.org/10.1016/j.jhevol.2018.11.012

\section{New data for the Early Upper Paleolithic of Kostenki (Russia)}

Rob Dinnis ${ }^{a^{*}}$, Alexander Bessudnov ${ }^{b}$, Natasha Reynolds ${ }^{c, d}$, Thibaut Devièse ${ }^{\mathrm{d}}$, Abi Pate ${ }^{\mathrm{e}}$, Mikhail Sablin $^{\mathrm{f}}$, Andrei Sinitsyn ${ }^{\mathrm{b}}$, Thomas Higham ${ }^{\mathrm{d}}$

${ }^{a}$ The British Museum, Franks House, 56 Orsman Road, London N1 5QL, UK

${ }^{\mathrm{b}}$ Institute for the History of Material Culture, Russian Academy of Sciences, Dvortsovaia naberezhnaia 18, 191186 Saint Petersburg, Russia

${ }^{\mathrm{c}}$ UMR 5199 PACEA, Université de Bordeaux, Bâtiment B8, Allée Geoffroy Saint Hilaire, CS 50023, 33615, Pessac Cedex, France

${ }^{\mathrm{d}}$ School of Archaeology, University of Oxford, 1-2 South Parks Road, Oxford OX1 3UB, UK

e Independent researcher, Edinburgh, UK

${ }^{\mathrm{f}}$ Zoological Institute, Russian Academy of Sciences, Universitetskaya nab. 1, 199034 Saint Petersburg, Russia

* Corresponding author.

E-mail address: rdinnis@britishmuseum.org (R. Dinnis). 


\section{Abstract}

Several questions remain regarding the timing and nature of the Neanderthal-anatomically modern human (AMH) transition in Europe. The situation in Eastern Europe is generally less clear due to the relatively few sites and a dearth of reliable radiocarbon dates. Claims have been made for both notably early AMH and notably late Neanderthal presence, as well as for early AMH (Aurignacian) dispersal into the region from Central/Western Europe. The Kostenki-Borshchevo complex (European Russia) of Early Upper Paleolithic (EUP) sites offers high-quality data to address these questions. Here we revise the chronology and cultural status of the key sites of Kostenki 17 and Kostenki 14. The Kostenki 17/II lithic assemblage shares important features with Proto-Aurignacian material, strengthening an association with AMHs. New radiocarbon dates for Kostenki 17/II of 41-40 ka cal BP agree with new dates for the recently excavated Kostenki 14/IVw, which shows some similarities to Kostenki 17/II. Dates of $\geq 41$ ka cal BP from other Kostenki sites cannot be linked to diagnostic archaeological material, and therefore cannot be argued to date AMH occupation. Kostenki 14's Layer in Volcanic Ash assemblage, on the other hand, compares to Early Aurignacian material. New radiocarbon dates targeting diagnostic lithics date to 39-37 ka cal BP. Overall, Kostenki's early EUP is in good agreement with the archaeological record further west. Our results are therefore consistent with models predicting interregional penecontemporaneity of diagnostic EUP assemblages. Most importantly, our work highlights ongoing challenges for reliably radiocarbon dating the period. Dates for Kostenki 14 agreed with the samples' chronostratigraphic positions, but standard pre-treatment methods consistently produced incorrect ages for Kostenki 17/II. Extraction of hydroxyproline from bone collagen using prep-HPLC, however, yielded results consistent with the samples' chronostratigraphic position and with the layer's archaeological contents. This suggests that for some sites compound-specific techniques are required to build reliable radiocarbon chronologies.

Keywords: Early Upper Paleolithic; Anatomically modern humans; Radiocarbon dating; Kostenki; Eastern Europe; Bladelet technology 


\section{Introduction}

Due to the overall paucity of diagnostic skeletal remains, the timing and nature of anatomically modern human (AMH) dispersal into Europe and the demise of Neanderthals is reconstructed largely via archaeological proxies, with different archaeological assemblage types taken to represent biologically distinct populations (e.g., Higham et al., 2014; Hublin, 2015; Kadowaki et al., 2015; Roussel et al., 2016; Teyssandier and Zilhão, 2018). The biological transition is broadly coeval with the appearance of Early Upper Paleolithic (EUP: 37-30 ka $\mathrm{BP}^{1}$; 42-34 ka cal BP) assemblages, while preceding European Late Middle Paleolithic (LMP) assemblages are generally accepted as being made by Neanderthals.

The earliest assemblages generally agreed to be of AMH authorship are Proto- and Early Aurignacian (Zilhão, 2013; Higham et al., 2014; Nigst et al., 2014; Benazzi et al., 2015; Hublin, 2015; Kadowaki et al., 2015; Roussel et al., 2016; Teyssandier and Zilhão, 2018). The chronology of sites dating to this period is still the subject of active research, but broadly appears to fit the periods $\sim 41-39 \mathrm{ka}$ cal BP for Proto-Aurignacian and $\sim 39-36 \mathrm{ka}$ cal BP for Early Aurignacian sites (using IntCal13; Supplementary Online Material [SOM] S1, Fig. S1 and Table S1; Jöris and Street, 2008; Banks et al., 2013a,b; Wood et al., 2014).

Proto-Aurignacian lithic assemblages are characterized by: fully Upper Paleolithic blade(let) production (i.e., with platform abrasion and marginal percussion) employing unipolar strategies; production of relatively light blades; a strong emphasis on the production of large bladelets with straight or only slightly curved profiles; and a retouched bladelet assemblage characterized by marginal retouch, including examples of alternate/ventral retouch (i.e., Dufour subtype Dufour bladelets). These bladelets are thought to have served as

\footnotetext{
${ }^{1}$ Radiocarbon determinations are reported as conventional radiocarbon ages 'BP', with BP representing before $1950 \mathrm{AD}$. Calibrated radiocarbon ages are reported as ages 'cal BP'. We used OxCal 4.3 (Bronk Ramsey, 2009) and the IntCal13 calibration curve to calibrate the radiocarbon ages (Reimer et al., 2013).
} 
component parts of hunting equipment (Broglio et al., 2005; O'Farrell, 2005; Normand et al., 2009), marking a tangible behavioral difference from preceding assemblages (Teyssandier and Zilhão, 2018). Early Aurignacian lithic assemblages differ from Proto-Aurignacian primarily in the prevalence of blades bearing heavy Aurignacian retouch, including strangulated/notched types, and the presence of smaller modified bladelets with curved but generally untwisted profiles, found in association with their parent wide-faced carinated cores.

Beyond the general consensus that Proto- and Early Aurignacian assemblages were created by AMHs, much remains unclear about how and when Neanderthal extinction and initial AMH occupation occurred. Substantial disagreements exist over: a) the attribution to AMH or Neanderthals of earlier or penecontemporary assemblages (Bohunician, Uluzzian, Châtelperronian, Streletskian, Spitsynian: Anikovich et al., 2007; Hoffecker, 2009; Benazzi et al., 2011; Müller et al., 2011; Zilhão, 2011; Hublin, 2015; Hoffecker et al., 2016; Vishnyatsky, 2016; Bataille, 2017); b) the validity of particular artifacts as markers of specific archaeological assemblages (and, by extension, of AMHs/Neanderthals; e.g., Slimak et al., 2011; Zwyns et al., 2012; Nigst et al., 2014; Moreau et al., 2015; Teyssandier and Zilhão, 2018); and the association of dated samples with diagnostic material (e.g., Nigst et al. 2014; Teyssandier and Zilhão 2018).

A more fundamental disagreement concerns the observability of directions and dynamics of dispersals from archaeological proxies given the current resolution of our chronometric methods. For some, the origins and spread of specific cultural phenomena are evident from the data (e.g., Higham et al., 2012, 2013; Nigst et al., 2014; Davies et al., 2015), while for others such perceived origins and spreads instead result from inconsistent and sometimes plainly erroneous data (e.g., Banks et al., 2013a,b; Teyssandier and Zilhão, 2018). The ongoing problems with accurately radiocarbon dating the period 50-30 ka cal BP lie at the 
root of much of this debate (Higham 2011; Alex et al., 2017; Devièse et al., 2017; this paper). To address these issues, further reliable archaeological and chronometric data are needed, especially for regions whose archaeological records are less well understood. The present study tackles these outstanding questions with new work on the EUP of Eastern Europe.

\section{The Neanderthal-AMH transition in Eastern Europe}

Despite its position adjacent to putative routes of $\mathrm{AMH}$ dispersal into Europe, the timing and dynamics of the Neanderthal-AMH transition in Eastern Europe are currently particularly unclear. A paucity of sites on the East European Plain is compounded by serious problems with the radiocarbon chronologies of key sites and sequences (Damblon et al., 1996; Sinitsyn, 1996; Sinitsyn et al., 1997; Douka et al., 2010; Demidenko and Noiret, 2012a; Marom et al., 2012). Additionally, uncertainty surrounds the Streletskian, which includes assemblages seen as representing a 'transitional' industry of Eastern Europe (Vishnyatsky, 2016; Dinnis et al., 2018). Most researchers consider all Streletskian assemblages as indicators of AMHs, either directly (Vishnyatsky and Nehoroshev, 2004; Anikovich et al., 2007; Kozłowski, 2014; Otte, 2014; Hoffecker et al., 2016; Vishnyatsky, 2016) or through acculturation of Neanderthals by incoming AMHs (Anikovich, 1999; Cohen and Stepanchuk, 1999). However, early Streletskian sites contain no human skeletal evidence to support either premise.

Long-lasting Neanderthal refugia have been suggested for several areas. Slimak et al. (2011) argued for Neanderthal presence close to the Arctic Circle at $\leq 34 \mathrm{ka}$ cal BP based on the perceived LMP nature of the Byzovaya lithic assemblage, although for Zwyns et al. (2012) the assemblage falls within the range of variation of the Streletskian and therefore does not indicate Neanderthal presence. To the south, claims for refugia in the Caucasus and Crimea (Ovchinnikov et al., 2000; Chabai, 2003) have been contradicted by more recent work (Adler et al., 2006, 2008; Jöris et al., 2011; Pinhasi et al., 2011). 
At the same time, claims have been made for early AMH occupation, based largely on evidence from the Kostenki-Borshchevo site complex in the Middle Don region. Various EUP assemblages at Kostenki have been argued to mark AMH presence prior to $40 \mathrm{ka}$ cal BP (Anikovich et al., 2007; Zwyns et al., 2012), although skeletal evidence to support this is sparse, fragmentary and ambiguous (Boriskovskii et al., 1982; Goebel, 2007; Zilhão, 2011; Sinitsyn, 2016a). If AMH authorship of all Streletskian assemblages is accepted, then recent radiocarbon dates for Layer V of Kostenki 1 (Haesaerts et al., 2017) ostensibly push AMH occupation at Kostenki back to $\sim 45 \mathrm{ka}$ cal BP (but see Discussion, below). With reference to more secure archaeological proxies, Hoffecker et al. (2016) have argued that AMHs using Aurignacian technology appeared later in Eastern Europe than in Central/Western Europe, with Proto-Aurignacian/Aurignacian assemblages from Kostenki and Siuren I (Crimea) representing an eastward dispersal.

\section{Kostenki-Borshchevo}

The Kostenki-Borshchevo complex (Voronezh region, Russia) includes numerous multilayered Upper Paleolithic sites and large archaeological assemblages, and offers a unique record of the Eastern European EUP. Nine of Kostenki-Borshchevo's 26 Upper Paleolithic sites have yielded at least one convincing EUP layer: Kostenki 1, 6, 8, 11, 12, 14, 17, and Borshchevo 4 and 5. The sites are positioned within and around a series of ravines that cut a chalk plateau meeting the western edge of the floodplain of the Don River (Fig. 1). The geological context of the Kostenki-Borshchevo archaeological deposits has been subject to considerable research and is now generally well understood (Rogachev, 1957; Lazukov, 1982; Holliday et al., 2007; Velichko et al., 2009; Sedov et al., 2010; Sinitsyn, 2014; Hoffecker et al., 2016). EUP material is found within, and between, two paleosol complexes: the Lower Humic Bed (LHB) and the stratigraphically higher Upper Humic Bed (UHB). At 


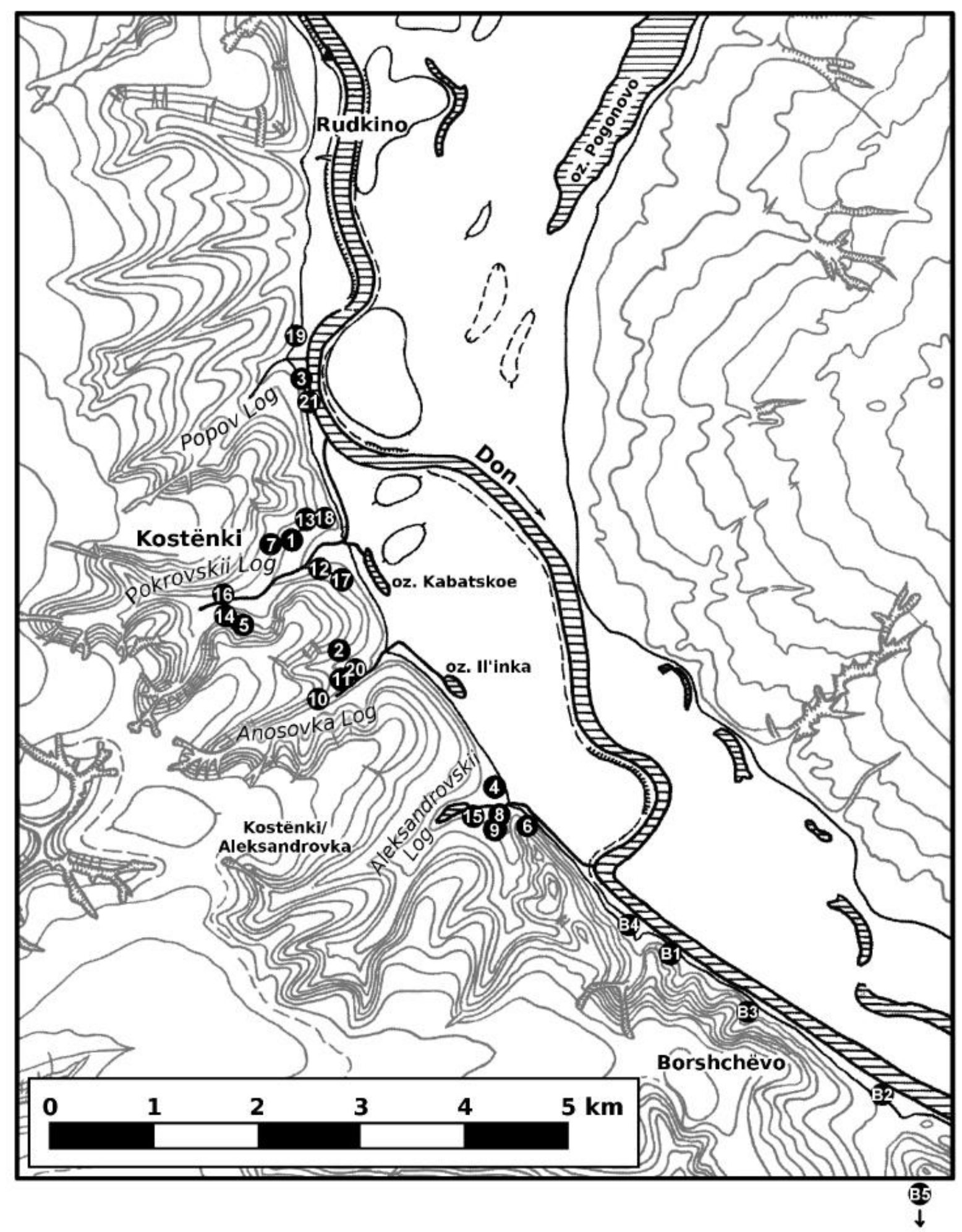

Figure 1. Location of the different sites within the Kostenki-Borshchevo complex. The Kostenki sites are marked as 1-21 and the Borshchevo sites as B1-B5. 
some sites these paleosol complexes are separated by a layer containing lenses or concentrations of volcanic ash. This has been identified as the Campanian Ignimbrite (CI)/Y5 tephra, now dated according to a combined series of radiocarbon dates on charcoal to 34,290 \pm 90 BP, or $~ 39-38.5$ ka cal BP using IntCal 13 (Pyle et al., 2006; Giaccio et al., 2017).

The nature of the CI tephra differs between sites and between different areas of each site. At some sites it is visible to the naked eye as sometimes-large lenses (e.g., Kostenki 17, 6 and 14 (Praslov and Rogachev, 1982), whereas at others it is present as concentrations of ash visible only with the aid of microscopy (e.g., Kostenki 1 [Anikovich/Dudin excavations]; Hoffecker et al., 2016). In some cases, most notably at Kostenki 6, the ash has clearly been redeposited (Rogachev, 1957). However, there is currently little to suggest that such processes have created inverted archaeological stratigraphies. The CI tephra therefore provides a crucial chronological marker. This is especially important because, despite the preservation of abundant bone and charcoal, successfully radiocarbon dating the Kostenki complex of sites has proved challenging (e.g., Damblon et al., 1996; Sinitsyn et al., 1997; Douka et al., 2010; Marom et al., 2012; Wood et al., 2012; Haesaerts et al., 2017; Reynolds et al., 2017).

Kostenki-Borshchevo therefore has the potential to provide high-resolution and, most importantly, verifiable radiocarbon chronologies. Furthermore, the presence of multiple sites means that the highest quality layers and areas can be targeted for analysis. This provides opportunities to circumvent the problems of mixing and/or ambiguity of archaeological material that exist at many EUP sites. Such high-quality data can help address not only questions regarding the timing of appearance of AMH-related archaeological material on the East European Plain, but also the fundamental issue of whether EUP cultural phenomena can be expected to display chronological clines between sites and regions. With these aims in 
mind, we undertook a new technotypological and chronometric analysis of KostenkiBorshchevo's most important EUP sites.

\section{Early EUP assemblages at Kostenki 17, Kostenki 14 and Kostenki 1}

Kostenki-Borshchevo's oldest EUP layers can be separated into those including retouched bladelets (or evidence for bladelet manufacture) and those characterized by Streletskian bifacial technology (Praslov and Rogachev, 1982; Anikovich, 1992, 2002; Bradley et al., 1995; Brantingham et al., 2004; Anikovich et al., 2007; Sinitsyn, 2014). Given the problematic nature of Kostenki's early Streletskian assemblages (see Discussion, below), the earliest assemblages that can be reasonably argued to have been created by AMHs are those with retouched bladelets from the sites of Kostenki 14, Kostenki 1 and Kostenki 17.

Kostenki 17 The main excavations at Kostenki 17 were undertaken by P.I. Boriskovskii in 1953 and 1955 (Boriskovskii, 1963; Boriskovskii et al., 1982; Fig. 2). Boriskovskii discovered two archaeological layers: the stratigraphically higher Layer I, positioned in the UHB; and the underlying and archaeologically richer Layer II, found in the top of the LHB, $\sim 6 \mathrm{~m}$ below the modern-day surface. Layer II was stratigraphically separated from Layer I by $\sim 3$ m of archaeologically sterile deposits. Within these sterile deposits, roughly halfway between Layers I and II, was a layer containing lenses of volcanic ash. Boriskovskii excavated Layer II over an area of $60 \mathrm{~m}^{2}$ (Boriskovskii, 1963). Small areas of the archaeological layer or contemporary deposits have been excavated since then (Rogachev, 1963; Praslov et al., 1980; Bessudnov, 2008), most recently in 2017-2018 by one of us (A.B.; Bessudnov et al., 2018). However, Boriskovskii's collection still constitutes $\sim 90 \%$ of the archaeological material excavated from this layer. 


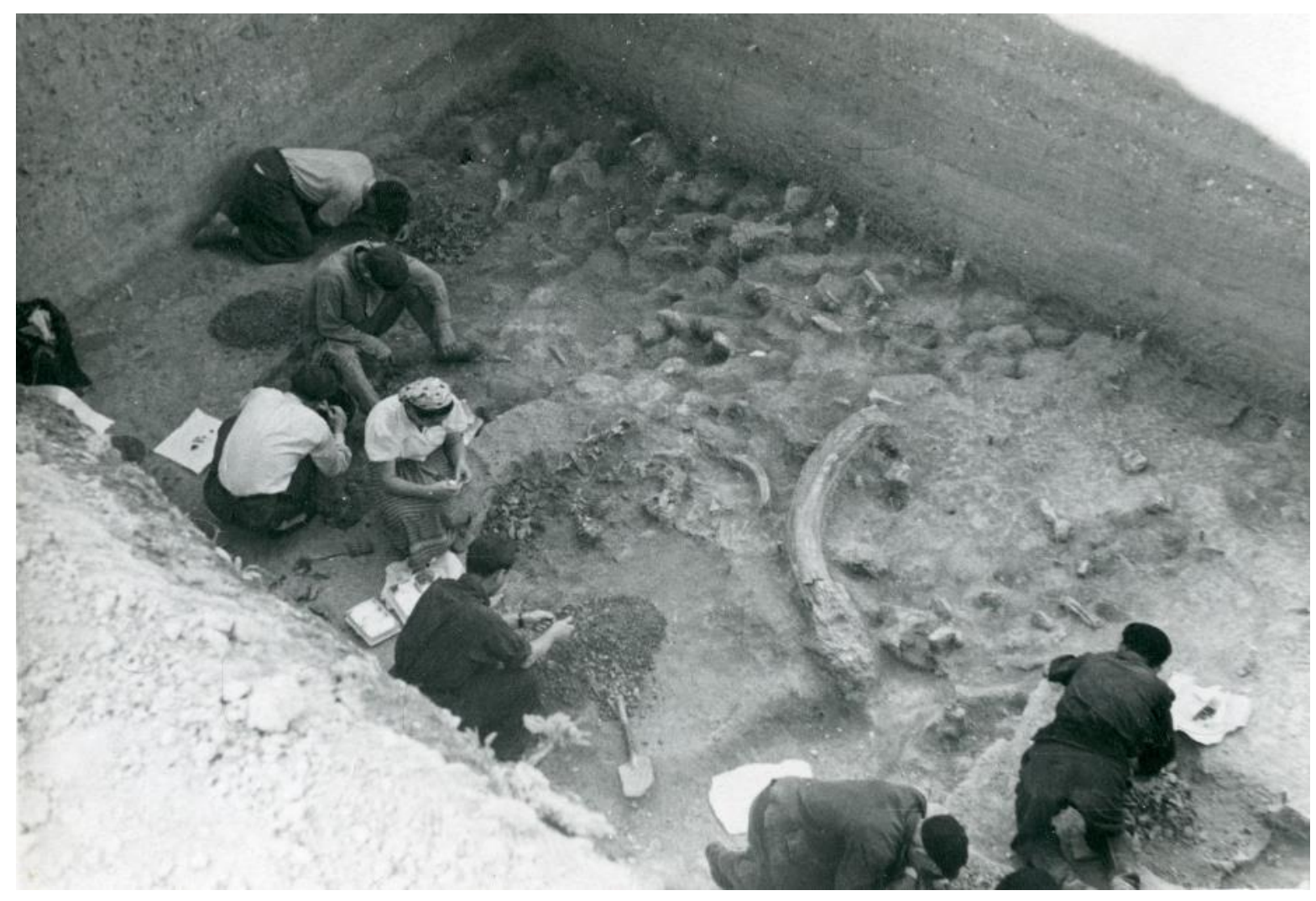

Figure 2. Excavation of Kostenki 17/I in 1953. Photo: Insitute for the History of Material Culture, Russian Academy of Sciences (IIMK RAN), archive reference O.1958-67.

Finds in Layer II were generally limited to a gently sloping 20-30 cm-thick horizon (Boriskovskii, 1963; Velichko, 1963). Boriskovskii (1963) and Velichko (1963) both considered the layer's contents to be mostly in situ, and subject to only minor downslope redeposition. The layer's lithic assemblage appeared unrolled and unweathered, and contained very small chips as well as larger pieces. In some places the layer was stained with red ocher, and concentrations of charcoal and ash in the NE and SW corners were interpreted as remnants of two hearths $>1 \mathrm{~m}$ in diameter, around which lay concentrations of archaeological material. In the central part of the trench were horse vertebrae and limb bones in anatomical position (Boriskovskii, 1963; Boriskovskii et al., 1982). 
Boriskovskii recovered a large lithic assemblage of $\sim 10,000$ pieces (Table 1), as well as a modest osseous tool assemblage of two awls made from arctic fox (or hare) ulnae and several fragmentary bone/ivory objects. The abundance of archaeological material within a relatively small excavated area led Boriskovskii (1963) to interpret the layer as evidence for a longterm settlement. Given the assemblage's size it may well represent a palimpsest of multiple phases of activity. Boriskovskii also found pendants made from fossil shells, carved stone and belemnites, along with a group of 37 fox canines perforated by rotary biconical drilling (SOM Files S1 and S2; Boriskovskii, 1963; Boriskovskii et al., 1982). The faunal assemblage comprised wolf, mammoth, horse, reindeer, bison and wolverine, with arctic fox represented by 37 pendants (Vereshagin and Kuz'mina, 1977; Boriskovskii et al., 1982). A single human molar found in the layer was tentatively attributed to Homo sapiens (Boriskovskii et al., 1982; Gerasimova et al., 2007), but it has never been the subject of complete study and for some researchers it is undiagnostic (e.g., Goebel, 2007; Zilhão, 2011).

Kostenki $17 / \mathrm{II}$ is usually referred to as 'Spitsynian', after the site's alternative name, Spitsynskaia. The only other assemblage to have frequently been described as Spitsynian is Layer II of Kostenki 12 (Anikovich, 1992; Anikovich et al., 2008; but see Sinitsyn, 2014). The use of this locally specific taxon highlights the historic difficulty of finding parallels for the assemblage outside Kostenki. Early comparisons (Chernysh, 1959; Boriskovskii, 1963) were made with assemblages now known to be much younger. Due to a perceived prevalence of heavily retouched blades, Grigor'ev (1968) and later Anikovich (2000; Anikovich et al., 2008) saw similarities with Aurignacian assemblages. However, it is important to note that when making this comparison the latter authors relied heavily on the small assemblage from Kostenki 12/II, which in our view is a mixed assemblage that probably includes Aurignacian artifacts. Boriskovskii's (1963) description of the Kostenki 17/II assemblage does not suggest the presence of aggressive, scaled/stepped Aurignacian-type edge retouch. Other researchers 
saw similarities to Gravettian material in the Kostenki 17/II assemblage, and suggested that the earlier age of Kostenki 17/II meant it represented the ancestor of later Gravettian assemblages (Kozłowski, 1986). More recently, Hoffecker and Holliday (2014) have referred to the assemblage as 'Proto-Gravettian', suggesting it represents a dispersal of AMHs into Eastern Europe different from, but broadly coeval with, an AMH Proto-Aurignacian dispersal around the Mediterranean. Others have stressed the lack of diagnostic elements that allow Kostenki 17/II to be described as either Aurignacian (e.g., Sinitsyn, 1997; Kozłowski and Otte, 2000; Demidenko, 2004; Vishnyatsky and Nehoroshev, 2004; Monigal et al., 2006; Usik et al., 2006) or Gravettian (Sinitsyn, 1997; Anikovich, 1992, 2000; Anikovich et al., 2008).

Despite these disagreements, the Kostenki $17 / \mathrm{II}$ assemblage is usually seen as evidence for AMHs at Kostenki; however, as Zilhão (2011) has argued, further evidence beyond its Upper Paleolithic nature is needed to warrant this conclusion. The position of Layer II below the CI tephra implies an age older than 39-38.5 ka cal BP (CI tephra $=34,290 \pm 90 \mathrm{BP}$ following Giaccio et al., 2017), but radiocarbon dates for the layer are either inconsistent with this or inconclusive (Table 2). One bone produced a date of 32,780 $\pm 300 \mathrm{BP}$ (LE-1436; i.e., younger than the tephra), while two dates from charcoal overlap with the tephra age but have notably large standard errors: $32,200 \pm 2000 / 1600 \mathrm{BP}(\mathrm{GrN}-10512)$ and 36,780 \pm 1700/1400 $\mathrm{BP}(\mathrm{GrN}-12596)$.

$\underline{\text { Kostenki } 14 \text { and Kostenki } 1}$ Early EUP archaeological assemblages with retouched bladelets have also been found at the better-known sites of Kostenki 14 and Kostenki 1.

As at Kostenki 17/II, the lowest layers of Kostenki 14 have been found within the LHB. Layer IVb is found in the eastern part of Kostenki 14. It comprises archaeological material deposited on the sloping sides of a paleogully and in the gully's base. The layer contained Upper Paleolithic lithic and osseous tool assemblages, a series of perforated shells, and a 
single human tooth, thought to be AMH (Sinitsyn, 2016a). Recently published dates for Layer IVb of 36.5-34 ka BP (Douka and Higham, 2017) are consistent with the material's chronostratigraphic position beneath the CI tephra.

On the western side of Kostenki 14 the lowermost identified archaeological layer is Layer IVw (the ' $\mathrm{w}$ ' refers to its western location). During its 2010-2015 excavation it was subdivided into IVw1 and the stratigraphically lower IVw2, which in some places were separated by a thin sterile layer and elsewhere were directly superimposed on one another, but are thought to reflect the same occupation horizon. Layer IVw2 is interpreted as the in situ remains of settlement activity, and Layer IVw1 as containing material that has been displaced downslope. Evidence for the undisturbed nature of Layer IVw2 includes a series of hare hindlimb bones found in anatomical position (Fig. 3). Layer IVw has yielded a series of pendants made from marine and freshwater mollusc shells and a lithic assemblage of $\sim 3,000$ pieces, including retouched bladelets. Although the lithic collection awaits full study, initial observations suggest some similarities with Kostenki 17/II (explained in Results, below).

Another layer at Kostenki 14, the Layer in Volcanic Ash (henceforth LVA), is stratigraphically higher than Layer IVw. Archaeological material in this layer has been subject to variable levels of postdepositional downslope displacement. Despite its apparent association with the CI tephra (=34,290 \pm 90 BP following Giaccio et al., 2017), published radiocarbon dates for the layer range from 20-35 ka BP (Table 3). Kostenki 14/LVA's small lithic assemblage contains diagnostically Aurignacian retouched bladelets, including Dufour bladelets (Sinitsyn, 2003). The retouched bladelets are 1-3 cm long and have curved but generally untwisted profiles. This kind of bladelet is typical of Early Aurignacian assemblages elsewhere in Europe (Pelegrin and O`Farrell, 2005; Le Brun-Ricalens et al., 2005; Michel, 2010; Chiotti et al., 2015; Bourrillon et al., 2017; Teyssandier and Zilhão, 2018). 

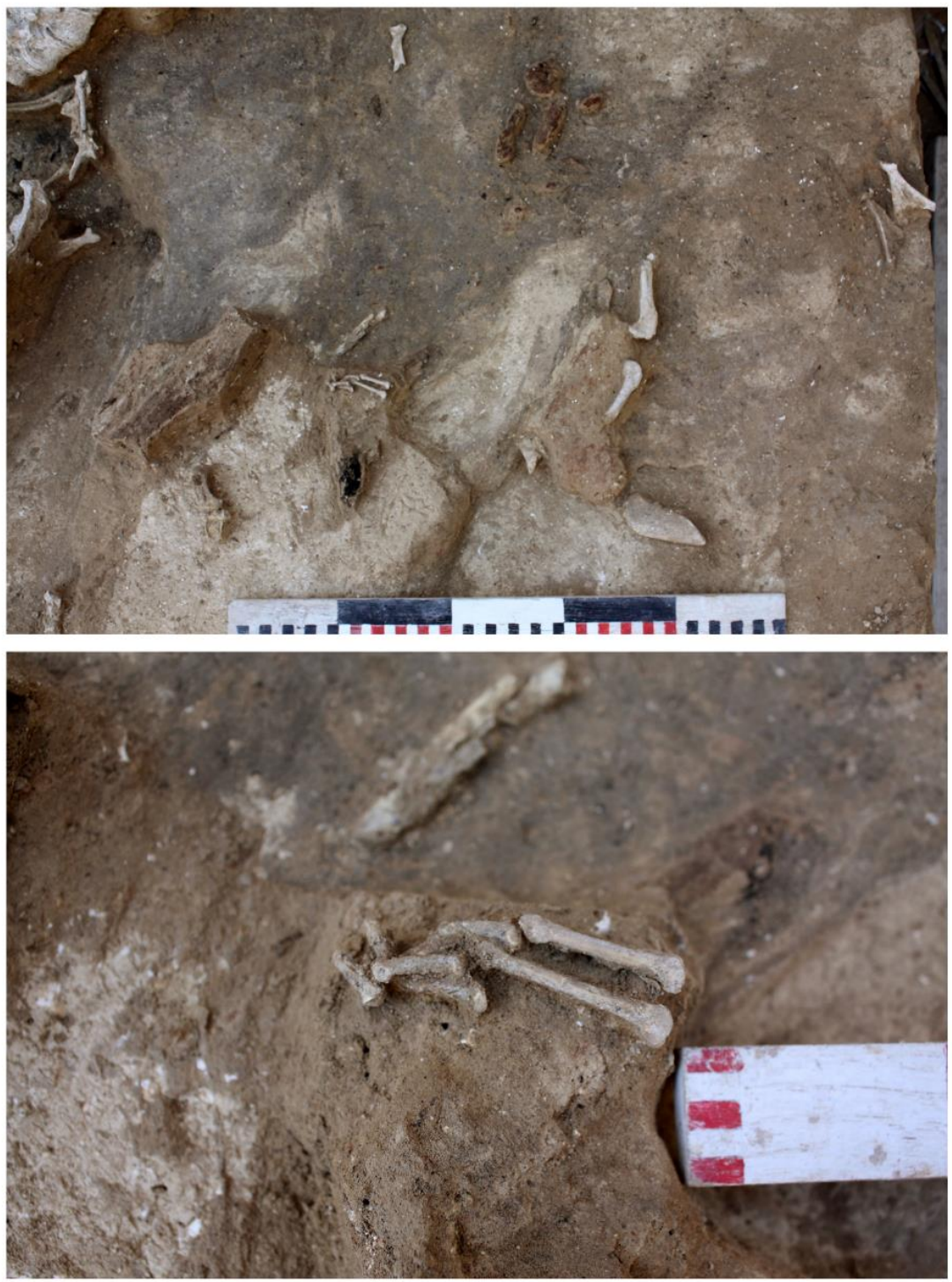

Figure 3. 2015 excavation of Kostenki 14/IVw2 (top) and close up of articulated hare hindlimb bones (bottom). Photos: A. Sinitsyn.

The Kostenki 14/LVA retouched bladelets are similar in their size and morphology to those from the Aurignacian assemblage of Kostenki 1/III (Sinitsyn, 1993, 2003), which was found within, and beneath, a buried soil that correlates to the UHB (Rogachev, 1957; Hoffecker and Holliday, 2014; Hoffecker et al., 2016). The Kostenki 1/III assemblage is larger than the Kostenki 14/LVA assemblage and contains carinated-scraper-cores with 
debitage faces sufficiently wide that bladelets produced were not systematically twisted (Fig. 4). It also contains pieces bearing heavy Aurignacian-type retouch, including one typical strangulated blade (Hahn, 1970; Sinitsyn, 1993; Fig. 4, bottom left). These features are characteristic of Early Aurignacian assemblages (Chiotti, 2005; Teyssandier and Zilhão, 2018).

\section{Materials and methods}

In order to revise the chronology of Kostenki's EUP retouched bladelet assemblages, we undertook new radiocarbon dating of Kostenki 17/II, Kostenki 14/IVw and Kostenki 14/LVA. We also undertook a new analysis of the Spitsynian lithic assemblage from Kostenki 17/II, to clarify its status as different from other known EUP assemblages. We focused particularly on the layer's retouched bladelets because these are the most diagnostic

and chronoculturally sensitive aspect of EUP lithic assemblages (e.g., Bon, 2002; Bon and Bodu, 2002; Bordes, 2005; Le Brun-Ricalens et al., 2005; Demidenko and Noiret, 2012b; Nigst et al., 2014; Dinnis and Flas, 2016; Falcucci et al., 2017; Tafelmaier, 2017).

\section{Radiocarbon dating}

Sampling was carried out on bones from Kostenki 14/LVA housed at the Institute for the History of Material Culture, Saint Petersburg, Russia. We targeted bones from the area where diagnostic Aurignacian material (i.e., the retouched bladelets) was found due to the complex depositional nature of the layer. Twenty-three of the layer's 24 retouched bladelets/fragments derive from a $15 \mathrm{~m}^{2}$ area, and together they form a coherent group consistent in their technological features and artifact condition. Of these 23,18 were found within a $2 \mathrm{~m}^{2}$ area. We therefore sampled four horse bones found in these two squares or squares immediately adjacent during the 2000 and 2003 excavations. 
For Kostenki 17/II, we sampled two fox tooth pendants housed at the Institute for the History of Material Culture (Saint Petersburg, Russia) and three wolf bones housed at the Zoological Institute (Saint Petersburg, Russia). All of this material comes from Boriskovskii’s excavations.

We also sampled three hare bones from Kostenki $14 / \mathrm{IVw}$, because of its potential similarity to Kostenki 17/II. The bones were all excavated from Layer IVw2 in 2015, and are housed in the Institute for the History of Material Culture.

Two different methods were used to prepare the samples for accelerator mass spectrometry (AMS) dating. First, samples were pretreated following the routine procedure at the Oxford Radiocarbon Accelerator Unit (ORAU) as described by Brock et al. (2010). This comprised decalcification in acid, a base wash, reacidification, gelatinization and ultrafiltration (coded 'AF' in the ORAU). Samples that had been preserved with glues, or samples for which we did not have complete knowledge of their post-excavation history, were washed with solvents (acetone, methanol and chloroform) prior to AF treatment (coded 'AF*' in the ORAU). Second, following the problems we encountered removing likely contaminants using this method (described below), some of the Kostenki 17 samples were also redated using the single amino acid radiocarbon dating method optimized at the ORAU (Devièse et al., 2018). This method involves separation of the underivatized amino acids from hydrolyzed bone collagen samples using preparative high-performance liquid chromatography (Prep-HPLC). The amino acid hydroxyproline, found almost uniquely in mammalian collagen, was isolated by Prep-HPLC, combusted, graphitized and AMS dated. This pretreatment approach (coded 'HYP' in the ORAU) is the most efficient available technique to remove contaminants including, but not limited to, conservation materials (with the exception of collagen-based glue). The technique has been applied successfully to a small 
粠 0 月

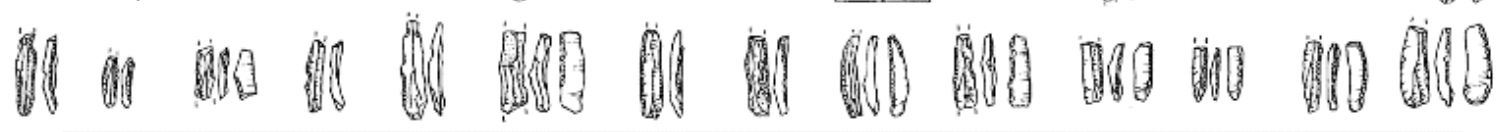
A

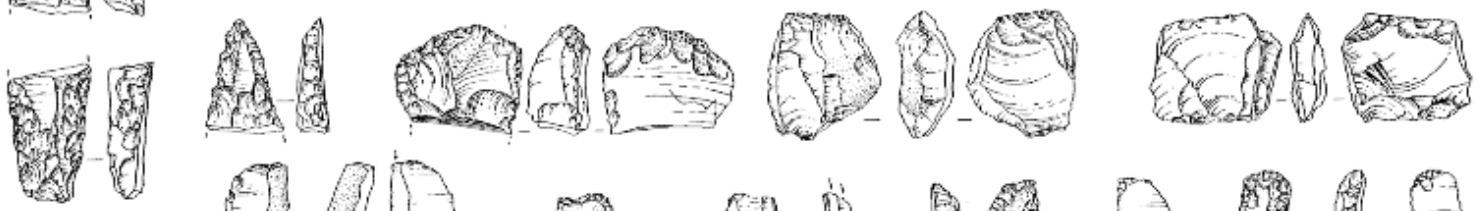

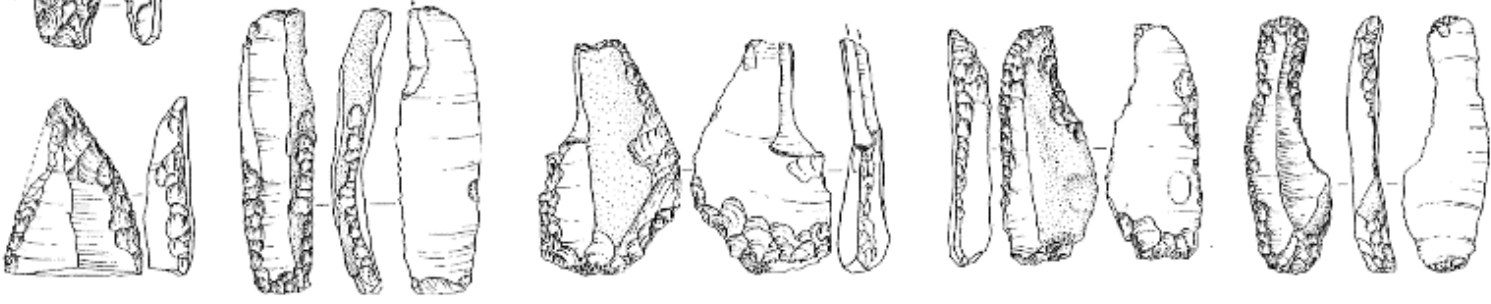

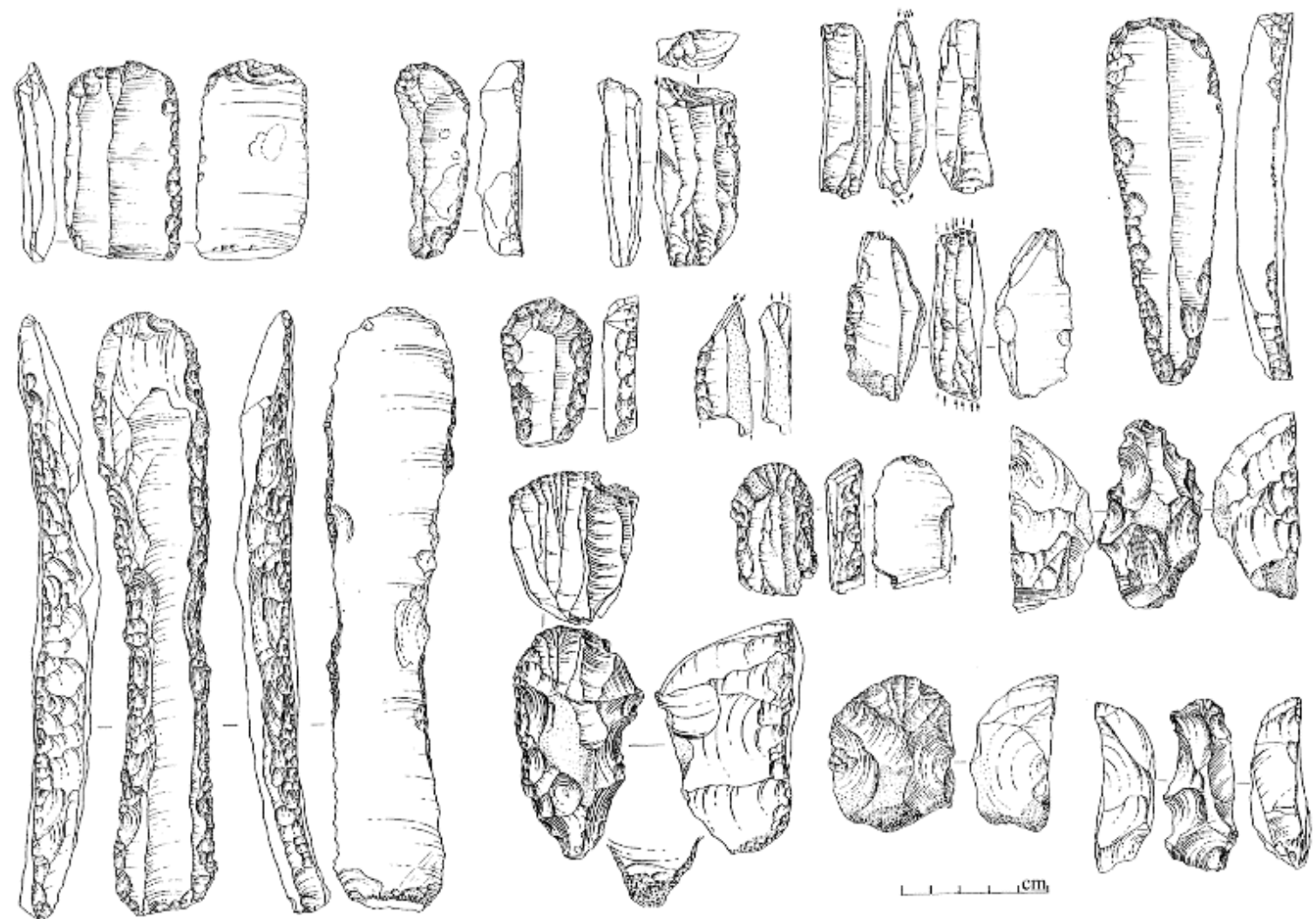

Figure 4. Lithic artifacts from the Aurignacian of Kostenki 1/III (reproduced from Sinitsyn, 1993). 

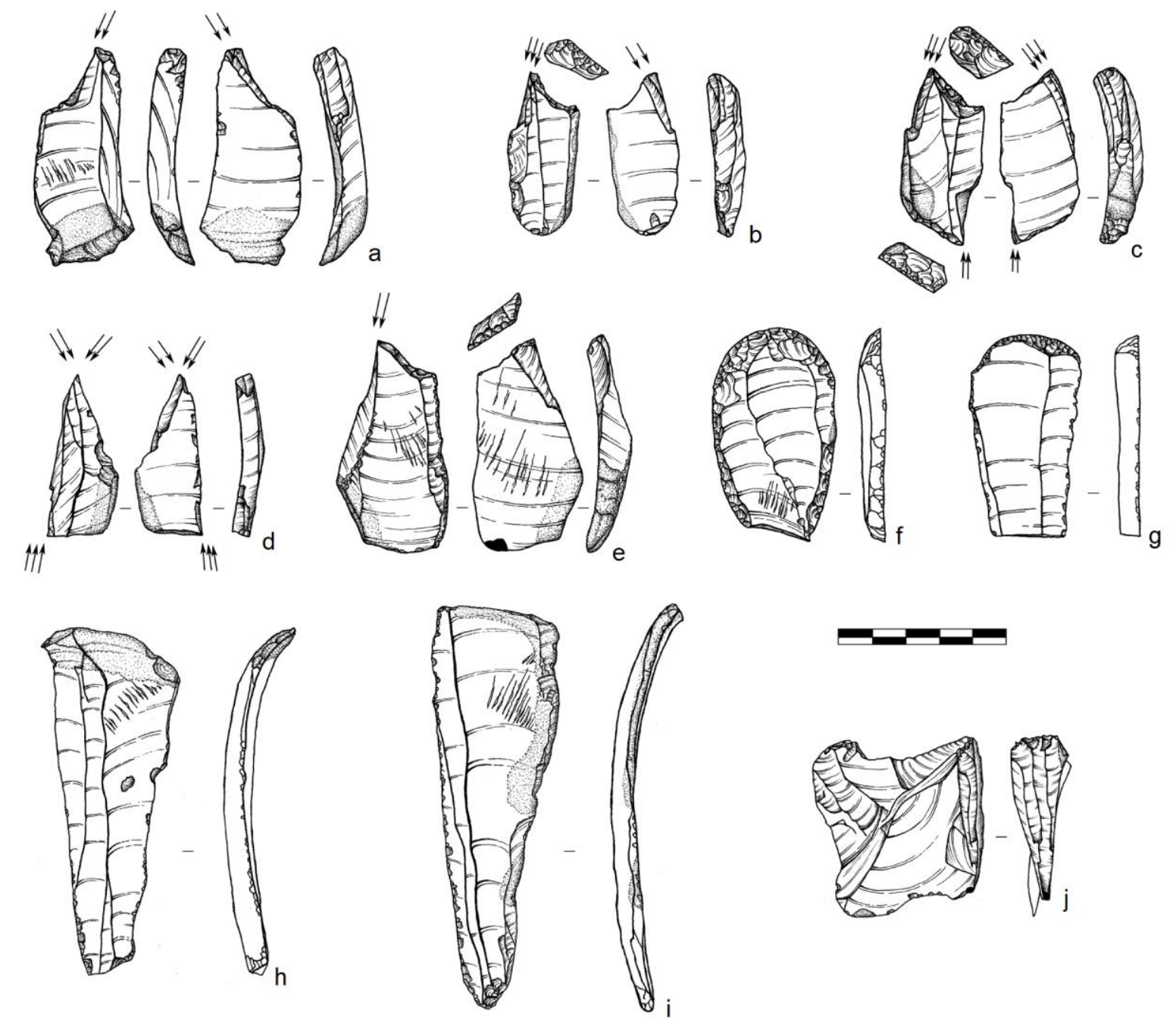

Figure 5. Part of the studied Kostenki 17/II lithic assemblage: burins (a-e), endscrapers (f, g), large blades (h, i) and bladelet core (j). Scale bar $=5 \mathrm{~cm}$.

number of contaminated Paleolithic bone samples (e.g., Bourrillon et al., 2017; Devièse et al., 2017; Reynolds et al., 2017).

\section{Kostenki 17/II lithic analysis}

To reassess the Kostenki 17/II assemblage we studied the entire available part of Boriskovskii's lithic collection ( $n=191$ pieces). The assemblage was composed of retouched pieces, cores and a very small proportion of the unretouched debitage, including larger blades 
and blade fragments (Fig. 5). Based on Boriskovskii's (1963) counts (Table 1) we estimate that we had access to roughly two-thirds of his total retouched assemblage, and that simple edge-retouched blades/fragments are underrepresented in our study. The whereabouts of the remainder of Boriskovskii's Layer II collection, including the vast majority of unretouched pieces, is currently unknown. Our study primarily utilized standard typological analysis, with technological and raw material characteristics noted where discernible. The material studied is housed at the Institute for the History of Material Culture. In addition, we consulted documentary material from Boriskovskii's excavations housed in the Insititute's archive.

\section{Results}

\section{Radiocarbon dating}

Kostenki 17/II Five new radiocarbon dates were produced from the fox tooth pendants (sample codes: K2014/1 and K2014/2) and wolf bones (sample codes: K17-01, K17-02 and K17-03). The former were visibly covered by conservation materials, so we applied the AF* pretreatment. There was no indication that preservatives had been applied to the wolf bones, but, as the curatorial history of the specimens was unknown, we also applied the same pretreatment to these samples. The two pendants produced ages of $26,830 \pm 250 \mathrm{BP}(\mathrm{OxA}$ $30824)$ and 25,480 \pm 220 BP (OxA-30825), while the three bones K17-01, K17-02 and K1703 were dated to $32,350 \pm 450 \mathrm{BP}(\mathrm{OxA}-32594), 31,250 \pm 400 \mathrm{BP}(\mathrm{OxA}-32595)$ and 33,050 \pm 500 BP (OxA-32596), respectively (Table 4; SOM Table S2).

All five dates are younger than the age assigned for the CI tephra, and are therefore incompatible with their chronostratigraphic position within the Kostenki 17 sequence. Furthermore, the range of ages produced was incompatible with the nature of the archaeological material from the layer. The similarity of the group of fox tooth pendants and their find locations suggest strongly that they constitute a single (contemporary) group of 
artifacts (Boriskovskii, 1963), but the two dates produced are significantly different. More generally, the large spread of these five dates is contradicted by the technotypological coherence of the layer's lithic material, which indicates that the layer relates to activity over a short period of time (see, e.g., Chiotti, 2005; Michel, 2010; Dinnis and Flas, 2016).

We hypothesized that the erroneous radiocarbon results may have been due to some contaminant that cannot be removed by routine $\mathrm{AF}^{*}$ pretreatment, and carried out further dating work. Two of the wolf bones (K17-01 and K17-03) were redated using the HYP method, using the surplus collagen obtained during the original $\mathrm{AF}^{*}$ treatment along with additional collagen obtained by resampling the bones. K17-01 was dated using the HYP method to $35,650 \pm 690 \mathrm{BP}(\mathrm{OxA}-\mathrm{X}-2677-56)$ and $\mathrm{K} 17-03$ to $36,020 \pm 740 \mathrm{BP}$ (OxA-X2677-57). Although there was some surplus collagen available for each of the fox tooth pendant samples, the amounts were individually insufficient for application of the HYP method, and no material was available for resampling. A third HYP date was therefore produced using the combined surplus collagen from the two fox tooth pendant samples. Although combining collagen from two different pendants is not ideal, their archaeological context, described above, strongly suggest that they are contemporary. The combined sample from the two pendants was used to produced a HYP date of 35,840 $\pm 520 \mathrm{BP}(\mathrm{OxA}-\mathrm{X}-2717$ 26). The three new results of $\sim 36-35.5 \mathrm{ka}$ BP are internally consistent and consistent with the layer's chronostratigraphic position beneath the CI tephra (Table 4; Fig. 6).

$\underline{\text { Kostenki } 14 / \mathrm{IVw}}$ Samples from this layer were prepared using the standard AF procedure because the post-excavation history of all the sampled bones is known precisely, and no conservation treatment has been applied to them. The three dated bones produced results of 36.5-35.5 ka BP (Table 5; Fig. 6; SOM Table S3). The accuracy of these results is supported by their internal consistency and their agreement with Kostenki 14/IVw's 


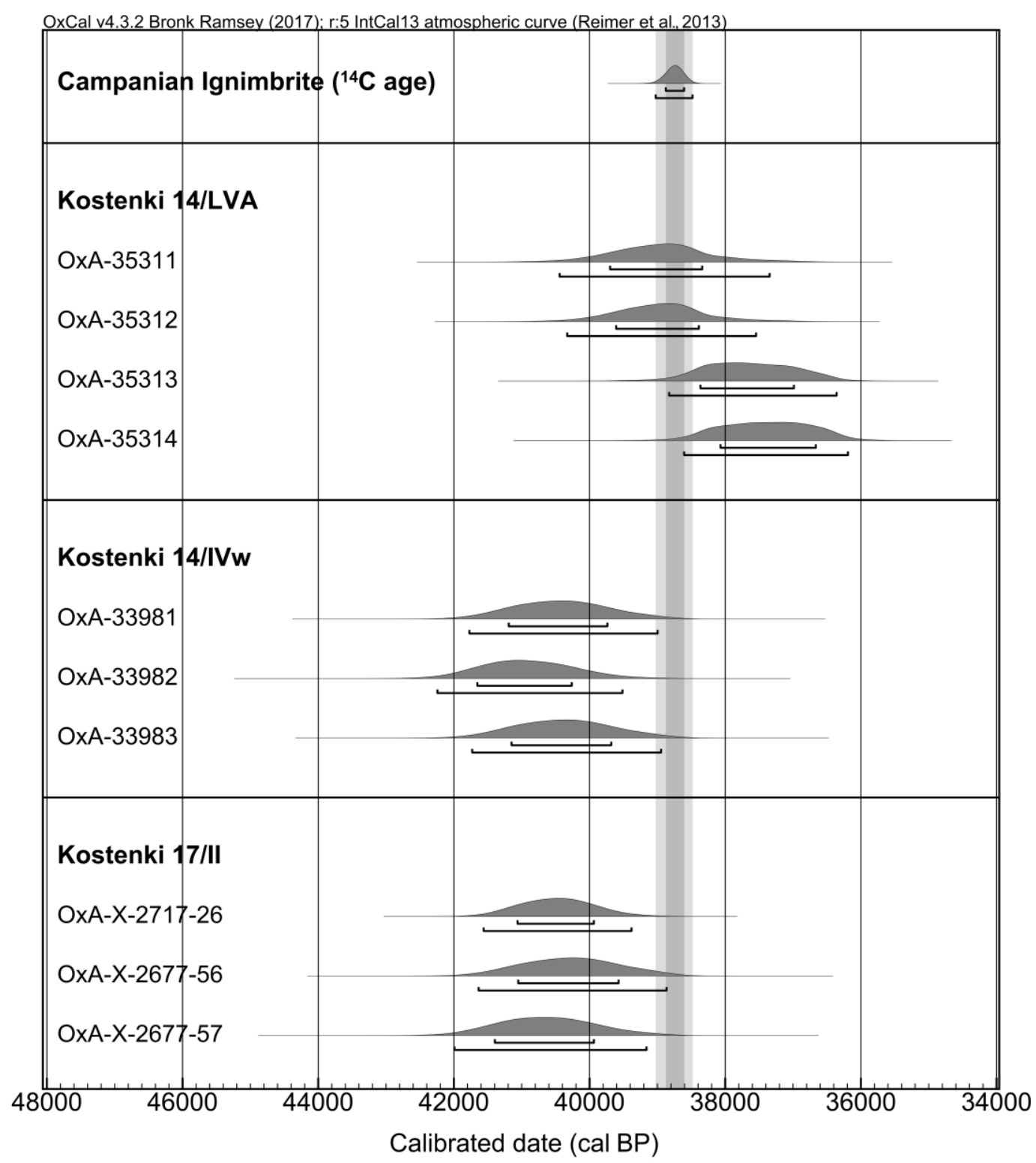

Figure 6. Calibrated ages for new radiocarbon dates from Kostenki 17/II (HYP dates only), Kostenki 14/IVw and Kostenki 14/LVA. The figure includes the age of the CI tephra following Giaccio et al. (2017).

chronostratigraphic position beneath the CI tephra (Table 5; Fig. 6). We also note their agreement with our HYP dates from Kostenki 17/II.

Kostenki 14/LVA Although we have a good knowledge of the curatorial history of the sampled material, we are aware that many people have examined it in the years since its excavation. As a precaution, we therefore applied the $\mathrm{AF}^{*}$ pretreatment. The results of 
$34,400 \pm 600 \mathrm{BP}(\mathrm{OxA}-35311), 34,400 \pm 550 \mathrm{BP}(\mathrm{OxA}-35312), 33,400 \pm 500 \mathrm{BP}(\mathrm{OxA}-$ $35313)$ and $33,150 \pm 500 \mathrm{BP}(\mathrm{OxA}-35314)$ are statistically indistinguishable from one another $\left(\right.$ mean $33,760 \pm 266 \mathrm{BP} ; \mathrm{T}^{\prime}=4.5$, df $\left.=3 ; \chi^{2}=7.81\right)$. Two of the determinations (OxA-35311 and -35312) overlap with the age ascribed to the CI tephra (Table 6; Fig. 6; SOM Table S4). The other two are statistically significantly younger, since their calibrated probability distributions do not overlap with 0 at $95.4 \%$ probability when we plot an OxCal Difference function comparing them with the calendar age of the CI. Overall, our results suggest that the archaeological material dates to the same time as the CI tephra or somewhat later. Either scenario is consistent with the site's stratigraphy as presently understood.

\section{Kostenki 17/II lithic analysis}

Raw materials/condition The assemblage that we studied from this site is dominated by flint (97\%, $n=186$ of 191), which is black, dark gray, dark brown or, more rarely, light brown in color. Some large blades ( $\geq 20 \mathrm{~mm}$ width) retain fresh cortex, suggesting they derive from large nodules extracted from a primary source. The origin(s) of the flint found at Kostenki is uncertain, but is thought to be at least $25 \mathrm{~km}$ distant, and possibly much farther (Boriskovskii, 1963; Yurgenson et al., 2012). Most material is unpatinated or lightly patinated to light gray or white. As was noted by Boriskovskii (1963), the overall assemblage is uniformly fresh in condition with only minimal edge damage and abrasion. This is consistent with it having undergone only minor postdepositional movement.

Blade production The assemblage includes 10 blade cores, of which one has been exploited as a bladelet core before discard. All are black or dark gray flint. Seven cores bear two or more flaking surfaces but only one has two opposite striking platforms, and in this case the second platform appears to have functioned only to maintain the core's longitudinal convexity (SOM File S3). General core morphology therefore indicates unipolar blade 
production. This is consistent with the dorsal/ventral scar pattern seen on the blades/blade segments and the curved profile of the large blades/segments (Fig. 5).

The dimensions of the studied blades/blade segments (Fig. 5) show that they were made on cores that were originally large in size. One group of complete/near-complete blades (Boriskovskii's 'large' blades; Table 1; Fig. 5h, i; SOM File S4) are $\geq 10 \mathrm{~cm}$ long and up to $38 \mathrm{~mm}$ wide, and many of the retouched pieces are made on portions of similarly large blades (Fig. 5; see also Boriskovskii, 1963). However, it should be noted that these pieces are disproportionately large in comparison to other blades described by Boriskovskii (1963) and in comparison with the final blade(let) removal negatives on the studied cores, whose widths range from 9-20 $\mathrm{mm}$. The lateral edges of the studied blades are generally straight and parallel/subparallel.

Thirteen large unmodified, retouched or crested blades retain their butts. Nine are facetted, with one showing dedicated isolation of the striking point (sensu Giria, 1997; see Dinnis et al., 2017). The remaining four are plain. Despite these blades' size, their butts are relatively small (average thickness $3 \mathrm{~mm}, n=13$ ). Preparatory abrasion of the core edge is discernible on $85 \%$ of them $(n=11)$, and $85 \%(n=11)$ are lipped. Bulbs of percussion are diffuse. Together these features indicate marginal percussion using a soft and possibly organic hammer (Pelegrin, 2000, 2012).

Burin-cores and bladelet production The Kostenki 17/II retouched assemblage is dominated by burins, and particularly burins on truncation (Table 1). The assemblage that we studied contains 138 burins, of which 32 are double. Their blanks are mostly blades/blade segments (79\%; $n=109$ of 138), although large flakes and core preparation/maintenance pieces (e.g., crested blades, core tablets) were also used (11\%;n=15). The platforms for burin removals were generally created by steep, oblique/concave retouched truncations (Tables 7 and 8; Fig. 5; SOM Files S5 and S6). Most burins are multifaceted, with 76\% of burin tips having two or 
more facets $(n=130$ of 170). The maximum number of facets is six (4\%, $n=6$ of 170) and the mean number is 3.8 .

This prevalence of burins suggests activity specialism at Kostenki 17. Boriskovskii (1963) noted usewear on some examples and suggested they may have served to pierce bone and other more malleable materials. However, prior to their discard many of these artifacts were apparently exploited as cores (e.g., Fig. 5a-c; SOM Files S5 and S6), an observation also made by Bataille (2013; see also comments by Boriskovskii, 1963). The incompleteness of the assemblage precludes confident assessment of the proportion that served as cores. However, we broadly agree with Bataille (2013), who concluded that $\sim 20$ of the Kostenki 17/II burins have convincing burin-core morphology but that the true number of burin-cores in the collection is higher, and that bladelet production from burin-cores is the main focus of stone-working activity evident at the site. One bladelet core formed on the edge of a large flake (Fig. 5j) is conceptually comparable to the burin-cores.

Bladelet production, like blade production, followed a unipolar reduction strategy. Four modified bladelets and two burin spalls retain their butts: they are small (all $<2 \mathrm{~mm}$ ), bear evidence of core abrasion ( $n=5$ of 6$)$ and are sometimes lipped ( 2 of 6$)$. This suggests soft hammer percussion.

$\underline{\text { Retouched/modified bladelets }}$ The studied Kostenki 17/II assemblage contains six modified bladelets, of which five are complete/near-complete (Fig. 7; Table 9). All are straight in profile or only slightly curved. Four are made from the layer's predominant black/dark gray flint and bear mostly semiabrupt, marginal, dorsal retouch. Two of these four (Fig. 7c, e) demonstrably derive from burin-cores. The remaining two (Fig. 7a, f; SOM File S7) have semiabrupt inverse marginal retouch along their right edge and direct retouch on their left edge, thereby fulfilling the criteria of Dufour bladelets of Dufour subtype (Demars and Laurent, 1992). Although the raw material/patination of both is atypical for the layer (Table 
9), there is no stratigraphic or technological reason to dissociate them from the layer (SOM S2 and Fig. S2).
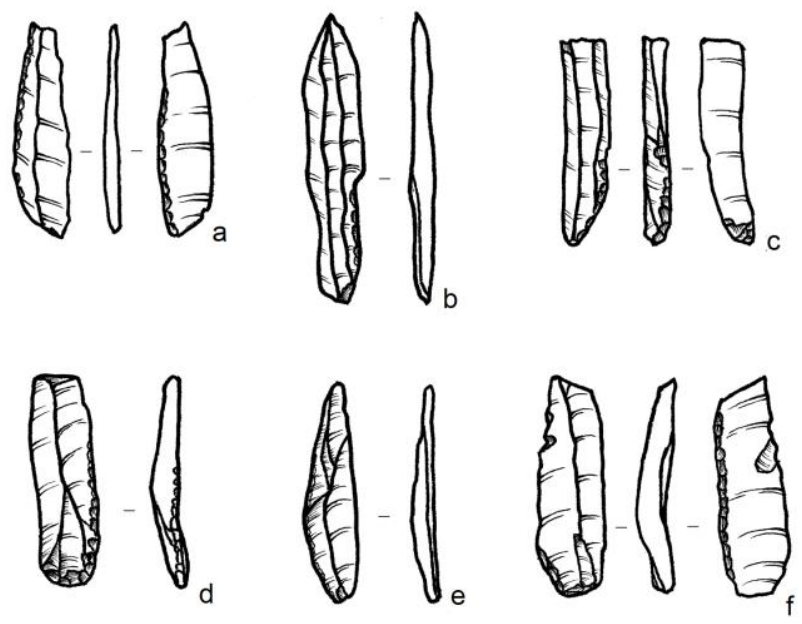

Figure 7. Kostenki 17/II modified bladelets: artifact numbers 1024 (a), 545 (b), 745 (c) 894 (d), 573 (e) and 188 (f). Scale bar $=5 \mathrm{~cm}$.

Although this is only a small sample, we can note technological similarities with ProtoAurignacian retouched bladelets from, e.g., Isturitz, Grotte du Renne and Les Cottés in France, Fumane in Italy, Kozarnika in Bulgaria, and Siuren I in Crimea (Perpère and Schmider, 2002; Sirakov et al., 2007; Normand et al., 2009; Tsanova et al., 2012; Falcucci et al., 2018). This includes: unipolar production employing core abrasion and marginal percussion; straight/slightly curved profiles; and similar size (Table 10). Examples with alternate retouch also show similarity in the lateralization of ventral/dorsal retouch on the right/left edges respectively, and the more invasive and uniform ventral retouch relative to dorsal retouch. The clearest point of difference with these Proto-Aurignacian modified bladelet assemblages is the use of the truncation-burin-core method of bladelet manufacture 
at Kostenki 17, which may help to explain the overall comparatively thicker blanks found there (Table 10).

In comparable EUP assemblages elsewhere most retouched bladelets are highly fragmentary. Falcucci et al. (2018) found that $>95 \%$ of examples in the Proto-Aurignacian collections from Les Cottés, Isturitz and Fumane were fragments. We can therefore infer that the six bladelets in Figure 7 represent only the most complete modified bladelets from the layer, and that many more fragments exist in the unstudied part of the collection. Despite this, we conclude that these six artifacts can be considered technologically representative of bladelet manufacture in the layer. First, their form and size agree well with the layer's burincores. Second, although we acknowledge the selected nature of the studied assemblage, we should presume that other types of retouched bladelet were not missed during excavation. Rogachev recovered a series of smaller retouched bladelets from Kostenki 1 in 1951, and Boriskovskii would therefore have been aware of the potential for similarly small pieces prior to his Kostenki 17 excavations. Boriskovskii (1963; see Table 1) also recorded 7,000 small retouch flakes and chips during his excavations, demonstrating a good rate of recovery of very small artifacts.

Comparisons with Kostenki 14 and Kostenki 1 retouched bladelet assemblages As described above, the lowest layers of Kostenki 14 (Layers IVb and IVw) are, like Kostenki 17/II, found in the LHB. Bladelet cores from Kostenki 14/IVb are unlike those that characterize Kostenki 17/II, and the lithic raw material profile of Layer IVb shows a notably greater prevalence of local colored flint than Kostenki 17/II (Bataille, 2013; Sinitsyn, 2014).

Rather, as noted above, Kostenki $17 / \mathrm{II}$ is more similar to Kostenki $14 / \mathrm{IVw}$. The Kostenki $14 / \mathrm{IVw}$ assemblage is, like that of Kostenki 17/II, dominated by imported flint, with a minimal amount of brown/yellow flint, chert and quartzite. Burins apparently served as cores 


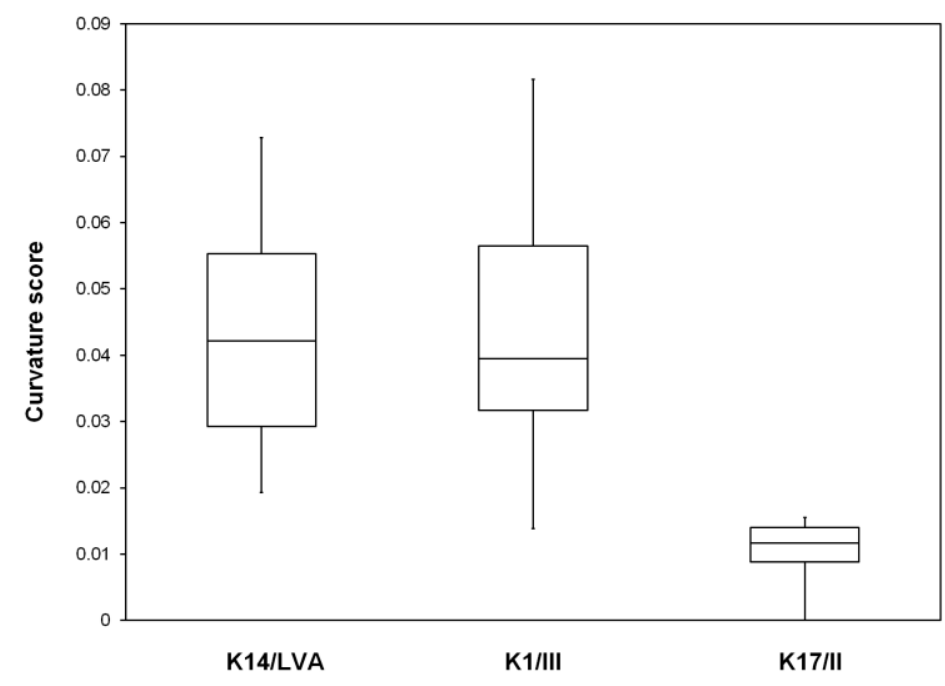

Figure 8. Box plot showing bladelet curvature scores for modified bladelets/fragments from Kostenki 14/LVA ( $n=16)$, Kostenki 1/III $(n=23)$ and Kostenki 17/II $(n=6)$. The whiskers denote the range of values and the boxes denote the first to third quartiles. The line within each box represents the second quartile (median). Curvature score calculated as maximum deviation from straight (to nearest $0.1 \mathrm{~mm}$ ) / length (to nearest 0.1 $\mathrm{mm})$. Fragments too small to allow measurements excluded. All measurements taken with digital calipers.

for the production of bladelets. So far, nine fragmentary modified bladelets/burin spalls have been identified from Layer IVw (four from IVw1 and five from IVw2), of which at least five derive from burin-cores. All bear abrupt/semiabrupt marginal dorsal retouch, in five cases bilateral and in four cases on one edge only. However, unlike at Kostenki 17/II, none bears ventral retouch.

The assemblages from Kostenki 14/LVA and Kostenki 1/III are chronostratigraphically later than Kostenki 17/II, and the modified bladelets found in these two assemblages differ from the Kostenki 17/II examples. They are shorter (1-3 cm long) and have comparatively curved profiles (Fig. 8). Furthermore, the carinated-scraper cores used to produce this type of bladelet are absent from Kostenki 17/II. 


\section{Discussion}

Radiocarbon dating the EUP and problematic bone dates from Kostenki

The difficulty in consistently producing accurate radiocarbon dates for the period 50-30 ka BP is now well established. The primary problem appears to be incomplete removal of exogenous carbon, which, when present in even very small amounts, tends to render radiocarbon measurements younger than the real age of the dated specimen (Higham et al., 2006, 2009; Jacobi et al., 2006; Brock and Higham 2009; Marom et al., 2012; Bird et al., 2014; Nalawade-Chavan et al., 2014; Wood, 2015; Alex et al., 2017; Bourrillon et al., 2017; Devièse et al., 2017; Reynolds et al. 2017; Sikora et al., 2017). Although the situation has improved over the last decade, the radiocarbon record for the LMP and EUP is still clearly problematic. Eastern Europe's most important EUP sites seem particularly badly affected. Considerable problems with the radiocarbon chronologies of Kostenki and Sungir' have been demonstrated to be the result of incomplete removal of contaminant exogenous carbon (Damblon et al., 1996; Sinitsyn, 1996; Sinitsyn et al., 1997; Douka et al., 2010; Marom et al., 2012; Reynolds et al., 2017). Similar issues probably also explain the problematic dates for the generally well-stratified EUP material from Siuren I (Demidenko and Noiret, 2012a).

At Kostenki, dates on bone have often proved particularly incompatible with their chronostratigraphic positions (Damblon et al., 1996; Sinitsyn et al., 1997). Only in the last few years have bones stratified within the LHB produced radiocarbon ages consistent with their position below the CI tephra (Douka and Higham, 2017; this paper). Our results highlight ongoing problems. Radiocarbon dates produced for Kostenki 14's EUP layers (Tables 5 and 6; Fig. 6) using a collagen ultrafiltration pretreatment are internally consistent and agree well with their chronostratigraphic position relative to the CI tephra. Douka and Higham's (2017) new dates for Kostenki 14, including those on bone, similarly agree with 
this chronostratigraphy. In contrast, however, bone dates for Kostenki 17/II produced using the same methods are erroneously young (Table 4).

How might we explain this discrepancy? The problems at Kostenki 17 potentially stem from post-excavation chemical treatment of bone/teeth. The new and apparently accurate bone dates for Kostenki 14 (Tables 5 and 6; Douka and Higham, 2017) were all produced from specimens excavated over the past two decades, and it is highly unlikely that any were treated with preservatives. Dated material from Kostenki 17, on the other hand, was excavated in the 1950s, and has a less clear post-excavation history. The dated pendants (OxA-30824 and OxA-30825), which initially produced radiocarbon ages $\sim 10,000$ radiocarbon years too young, were visibly glued (Table 4). Other visibly glued specimens from mid- $20^{\text {th }}$ century collections at Kostenki have likewise produced erroneously young ages (Marom et al., 2012; Reynolds et al., 2017). However, the Kostenki 17 wolf bones, whose initial radiocarbon ages were 5000-3000 radiocarbon years too young, bear no evidence of treatment (Table 4). This, of course, does not mean that they were not treated, and not enough is known of Kostenki's mid- $20^{\text {th }}$ century excavation and curatorial protocols to rule out routine treatment of bones, perhaps even at the point of excavation. Further dating work on Kostenki's EUP-age bone is in progress, and early indications are that mid-20 th century collections from other Kostenki sites can produce similarly incorrect results. Further work will be undertaken to determine whether we can in fact identify evidence for conservation treatment on the bones.

Alternatively, given that the wolf bones from Kostenki 17 show no sign of post-excavation chemical treatment, then other reasons for the erroneous radiocarbon dates must be considered. A useful comparison is found in Bourrillon et al.'s (2017) results for untreated bones associated with Early Aurignacian material at Abri Blanchard. Here too, standard methods (i.e., AF) produced ages that appear too young for the associated archaeological 
material. When redated using HYP pretreatment, the same bones yielded results that were 2500-4500 radiocarbon years older. This is consistent with contamination with younger carbon. Bourrillon et al. (2017) suggested that exogenous carbon may have derived from humates carried in groundwater, which could have cross-linked with collagen and become impossible to remove completely using standard pretreatment methods. Support for this comes from the adjacent site of Abri Castanet, where untreated bones associated with comparable archaeological material and similar (post)depositional circumstances also produced dates inconsistent with those for other Early Aurignacian assemblages nearby (Higham et al., 2011; White et al., 2012). If a similar mechanism has affected bones at Kostenki, it need not necessarily apply consistently to all Kostenki sites: Kostenki 17 is positioned in the main river valley whereas Kostenki 14 lies on the slope of a tributary ravine, and they will certainly have experienced different (post)depositional processes. The explanation offered for the incorrect dates from Abri Blanchard could therefore also explain the unreliability of dates from Kostenki 17 compared to Kostenki 14. One further factor to note is the open-air or near open-air nature of all these sites. Zilhão and d'Errico (2003) and Mellars (2006a) have previously suggested that radiocarbon dates of bone from inside caves and outside on porches exhibit markedly different results, with the latter often more significantly underestimating the real age.

More work is required to explore how widespread these anomalies might be, but currently we recommend caution in building radiocarbon chronologies for the LMP and EUP at single sites when radiocarbon dates produced cannot be verified or supported by other chronological information (e.g., inter-site stratigraphic correlations, other radiometric methods: see d'Errico and Banks, 2015). For Kostenki 17/II, our three initial dates of 33-31 ka BP for the wolf bones (Table 4) were in good agreement with a bone date produced previously at the Saint Petersburg laboratory and with one of the two dates on charcoal from the Groningen 
laboratory (Table 2). The wolf bones were not visibly treated and there is no indication from the sample measurements (e.g., C:N ratios) that these dates are questionable. However, the position of the layer beneath the CI tephra and subsequent redating using HYP pretreatment confirm that these dates are significant underestimates of the true age of the samples. Such a wealth of supporting evidence is obviously rarely available for LMP/EUP sites; therefore, given that they are less sensitive to such site-specific problems, models built on regional or supraregional data (e.g., Jöris et al., 2011; Banks et al., 2013a; Alex et al., 2017) are more appropriate to diagnose chronology.

Whatever it was that caused our initial, erroneous dates for Kostenki 17/II, the dates subsequently produced using HYP pretreatment appear to be reliable, as they ought to be given that they are on compound-specific single amino acid fractions (Table 4). As with previous applications of the method, they are internally consistent, consistent with independent stratigraphic markers and are in line with expectations based on associated archaeological material (Marom et al., 2012; Nalawade-Chavan et al., 2014; Bourrillon et al., 2017; Devièse et al., 2017; Reynolds et al., 2017).

\section{Streletskian early AMHs at Kostenki?}

Our results for the well-stratified layers Kostenki $17 / \mathrm{II}$ and Kostenki $14 / \mathrm{IVw}$ show that these two typically Upper Paleolithic assemblages (i.e., with 'Upper Paleolithic' blade/bladelet production and personal ornaments $)$ at Kostenki date to $\sim 36 \mathrm{ka} \mathrm{BP}(\approx 41 \mathrm{ka} \mathrm{cal}$ BP). This age is close to the older of the dates recently produced for the Upper Paleolithic assemblage from Kostenki 14/IVb (Douka and Higham, 2017), which occupies a similar stratigraphic position to Layer IVw.

Other layers at Kostenki are also thought to predate the CI tephra, most notably Layer III of Kostenki 12 and Layer V of Kostenki 1, where radiocarbon and OSL dates suggest an age 
equal to or in excess of $41 \mathrm{ka}$ cal BP (Praslov and Rogachev, 1982; Holliday et al., 2007; Levkovskaya et al., 2015; Haesearts et al., 2017). Both assemblages are usually referred to as Streletskian (e.g., Rogachev, 1957; Bradley et al., 1995; Anikovich et al., 2004; Bosinski, 2013; Sinitsyn, 2014), with a mixture of Upper and Middle Paleolithic characteristics (Anikovich, 2002; Anikovich et al., 2004; Bataille, 2013, 2016). Both have been argued to be evidence for early AMHs on the East European Plain (e.g., Vishnyatsky and Nehoroshev, 2004; Kozłowski, 2014; Otte, 2014; Hoffecker et al., 2016; Vishnyatsky, 2016).

Unlike Kostenki 17/II and Kostenki 14/IVw, however, neither Kostenki 12/III nor Kostenki 1/V can be considered per se as well-stratified/unmixed and well-dated. Kostenki 12/III was found within the LHB, but was positioned differently within it in different parts of the site (Rogachev, 1957; Anikovich et al., 2004; Levkovskaya et al., 2015). In northern (downslope) parts of the site, excavated in the 1950s and early 1960s, it was recognized that Layer III and the overlying Layer II were conflated over most of the excavated area, with lithic material separated into the two layers only post-excavation (Rogachev, 1957; Anikovich, 1977; Rogachev and Anikovich, 1982). More recent excavations in the site's southern (upslope) part have amply demonstrated that Layer III has been redeposited (Anikovich et al., 2004; Hoffecker et al., 2005, 2010; Holliday et al., 2007). Importantly, the condition of the horse bones found in the layer differs from that of the reindeer bones, indicating that they have different depositional histories. For Hoffecker and colleagues (Hoffecker et al., 2010; Hoffecker and Holliday, 2014) this is evidence that they were deposited at different times. Clearly the associated lithic assemblage cannot be presumed to be unmixed, particularly given its marked technotypological variation relative to the assemblages from the well-stratified Kostenki 14/IVw and Kostenki 17/II (Praslov and Rogachev, 1982; Anikovich et al., 2004; Bataille, 2013). 
Kostenki 1/V poses different problems. Rogachev's 1948-53 Layer V excavations yielded an apparently well-stratified lithic assemblage that included diagnostic Streletskian points (Rogachev, 1957; Rogachev et al., 1982; Hoffecker et al., 2016). However, the material found in Layer V during more recent work beyond Rogachev's excavation area is meager and mostly undiagnostic (Anikovich et al., 2008; Hoffecker et al., 2010, 2016). Unfortunately, all luminescence/radiocarbon dates for the layer come from excavations later than Rogachev's (Anikovich et al., 2007; Hoffecker et al., 2016; Haesaerts et al., 2017), and they cannot confidently be associated with Rogachev's finds. This includes the radiocarbon dates of $>42$ ka BP recently produced by Haesaerts et al. (2017). All diagnostic Streletskian points attributed to Kostenki 1/V come from the northern excavation area, whereas Haesaerts et al.'s (2017) dates are for samples from the southern excavation area, which is separated from the northern area by an unexcavated zone. This situation is exacerbated by the recent recognition that a part of Layer V in the southern excavation area, adjacent to where Haesaerts et al.'s (2017) dated samples came from, actually consists of more than one observable layer (Hoffecker et al., 2016). Haesaerts et al.'s (2017) dates therefore cannot be securely associated with the Layer V Streletskian assemblage found by Rogachev.

Since these radiocarbon dates from Kostenki 12/III and Kostenki 1/V cannot be confidently associated with diagnostic archaeological material, they cannot be argued to date Streletskian assemblages, and therefore cannot be attributed to AMHs. Further still, the blanket association between Streletskian assemblages and AMHs is itself problematic, given the high degree of variability and long chronological range found among Streletskian assemblages. While marked technotypological variety is usually implicitly accepted as representative of high diversity in Streletskian stone-working behaviors over a short period of time (e.g., see Bradley et al., 1995; Anikovich, 2002; Anikovich et al., 2004; Zwyns et al., 2012; Bosinski, 2013), in at least some cases it is equally if not more likely to result from 
mixing of material from different occupation events. It follows that some material in Kostenki's early Streletskian layers potentially reflects Neanderthal and not AMH activity.

\section{The place of the Spitsynian in the western Eurasian Early Upper Paleolithic}

The presence of pendants, bone tools and typically Upper Paleolithic blade/bladelet production and tool forms in the Kostenki 17/II assemblage has led to the general recognition that it is fully Upper Paleolithic and unrelated to LMP assemblages. However, finding analogies for the assemblage beyond Kostenki has proved difficult. Its typological and technological profile does not suggest a relationship with 'transitional' Eastern/Central European Streletskian or Szeletian (Allsworth-Jones, 1986, 1990: Bradley et al., 1995; Bataille, 2013; Mester, 2014). The fully Upper Paleolithic nature of the blade production and the importance of bladelet production marks it as different from the Near Eastern Initial Upper Paleolithic and the Central European Bohunician assemblages (Škrdla and Rychtaříková, 2012; Škrdla, 2014), as well as from the comparable industry from Layer II of Korolevo II in western Ukraine (Monigal et al., 2006; Usik et al., 2006). The absence of curved and/or twisted bladelet production distinguishes Kostenki 17/II from Aurignacian assemblages sensu stricto (i.e., excluding Proto-Aurignacian). Kostenki 17/II has also not yielded the steeply and invasively backed pieces that characterise Gravettian assemblages (Noiret, 2013). Furthermore, Early Gravettian sites across Europe, including at Kostenki, are close to 10 kyr younger than Kostenki's Spitsynian assemblages (Jöris et al., 2010; Higham et al., 2011; Reynolds et al., 2015). Any perceived link between the two should therefore be rejected.

One potential analogue for Kostenki's Spitsynian assemblages comes from the EUP Layer 3 of Sokyrnytsa I Area A in western Ukraine (Usik et al., 2006; Bataille, 2013): as at Kostenki 17/II there is evidence for typically Upper Paleolithic blade/bladelet production, 
burins are prevalent (including on concave truncations), carinates are absent, and bladelets with marginal dorsal retouch are present (Monigal et al., 2006; Usik et al., 2006; Bataille, 2013). Bataille (2013) has also suggested a possible link between Kostenki 17/II and EUP assemblages containing burins on truncation found in Layer $4 \mathrm{c} / 4 \mathrm{~d}$ of Ortvale Klde (Adler et al., 2006, 2008) and Layer D of Dzudzuana Cave (Bar-Yosef et al., 2011) in the Caucasus. Further study of burins and bladelet production at these sites would help to assess these proposed similarities, although we can note that, in contrast to Kostenki 17/II, no Dufour bladelets have been described for any of these assemblages. Further south, the Ksar Akil Phase 3 assemblage ( $\approx$ layers XIII-XI of the 1938 excavation) is, like Kostenki 17/II, characterized by Upper Paleolithic blade/bladelet production and is dominated by burins, including multifaceted burins on truncation (Bergman, 1988; Williams and Bergman, 2010). However, unlike Ksar Akil Phase 3, the studied Kostenki 17 assemblage is not characterized by twisted blades/bladelets.

Most significantly, the presence of Dufour (Dufour subtype) bladelets at Kostenki 17/II invites comparison with European Proto-Aurignacian assemblages and comparable EUP facies in the Levant (i.e., Ksar Akil Phase 4 [حlayers X-IX of the 1938 excavation]; Mellars, 2006b; Demidenko, 2012; Kadowaki et al., 2015). No Proto-Aurignacian material has so far been identified on the East European Plain, but several candidate assemblages have been described at its margins (Demidenko, 2004, 2009). The most important of these is from Siuren I in Crimea (Lower Layer of 1920s excavations, Units H/G 1990s excavations), 800 $\mathrm{km}$ south west of Kostenki. This lithic assemblage contains evidence for the production of bladelets with straight or only slightly curved profiles, with Dufour (Dufour subtype) bladelets and Krems points found among the retouched assemblage. Bladelets were produced from dedicated bladelet cores (Demidenko and Noiret, 2012b). Radiocarbon dates and the assemblage's stratigraphic position beneath later Aurignacian material confirm its MIS 3 age, 
but the radiocarbon data are too problematic to give a more precise chronology (Demidenko and Noiret, 2012a). The small, open-air surface collection from Chulek I, at the mouth of the Don River $\sim 500 \mathrm{~km}$ south of Kostenki, is similar to the Siuren I Proto-Aurignacian assemblage. Twelve of the site's 39 retouched bladelets have been classified as Dufour (Dufour subtype; Demidenko, 2009). The retouched assemblage contains a relatively high proportion of burins $(33 \% ; n=33$ of 100$)$ but these do not appear to have served as cores (Demidenko, 2009; Y. Demidenko, pers. comm. 2017). In the Northern Caucasus, the larger open-air site of Shirokii Mys is undated, but may also be compared to the Siuren I assemblage on technotypological grounds (Shchelinskiy, 2007). Of a group of 697 retouched bladelets found at Shirokii Mys, Demidenko (2009) described 15\% ( $n=104)$ as typical Dufour (Dufour subtype) bladelets, and a further 9\% $(n=61)$ as Krems points. Bladelet production was from dedicated subpyramidal and subcylindrical cores, with a few carinated bladelet cores also represented (Demidenko, 2009). In addition, the lower layer from the nearby Kamennomostskaya Cave yielded a mixture of Micoquian and Upper Paleolithic material including Dufour bladelets. Bladelets were produced from dedicated prismatic bladelet cores and from the edge of large flakes (Demidenko, 2009). To the west, Beregovo I in the Transcarpathia region of Ukraine has been described as Proto-Aurignacian (Usik, 2008; Usik et al., 2013), as have several sites west of the Black Sea (e.g., Kozarnika VII, Tincova, Româneşti-Dumbrăviţa I; Sirakov et al., 2007; Demidenko and Noiret, 2012b; Tsanova et al., 2012, Schmidt et al., 2013).

A significant degree of variability is now evident in these and other assemblages described as Proto-Aurignacian. Bladelet production proceeded either from blade cores, dedicated bladelet cores, or along the edge of large flakes, which were sometimes configured as burincores (Bon, 2002; Bon and Bodu, 2002; Bordes, 2005; Demidenko, 2009; Porraz et al., 2010; Demidenko and Noiret, 2012b; Tsanova et al., 2012; Bataille, 2016; Falcucci et al., 2017; 
Tafelmaier, 2017). However, despite this variation, these assemblages all share two features: significant evidence for relatively large modified bladelets with straight or only slightly curved profiles, and the presence of Dufour (Dufour subtype) bladelets among the retouched assemblage (Demidenko and Noiret, 2012b; Anderson et al., 2015; Falcucci et al., 2018). Although Kostenki 17/II shows some clear differences from these other assemblages-most notably in the production of large blades and the truncation-burin-core method of bladelet manufacture - both of these features are present. For this reason, it should be viewed as a local variant of the Proto-Aurignacian elsewhere. This is consistent with the shared chronological position of Kostenki 17/II and Proto-Aurignacian assemblages (Table 4). In addition, evidence from Kostenki 14 directly links Kostenki with areas with/near to ProtoAurignacian occupation around this time: a perforated Columbellidae shell from Layer IVb derives from the Mediterranean Basin, and several perforated shells from Layer IVw are probably from the Black Sea region (Sinitsyn, 2016b).

The Proto-Aurignacian features of the Kostenki 17/II assemblage support the hypothesis that it represents early AMHs, and therefore AMH occupation of the Middle Don region by 36 ka BP (41 ka cal BP), when Proto-Aurignacian sites evidence early AMH occupation elsewhere in Europe. A Proto-Aurignacian-like assemblage at Kostenki not only extends the known geographical limits of this assemblage type into the East European Plain, but also extends the known range northwards. This is significant given the often-noted southern European distribution of Proto-Aurignacian sites (Mellars, 2006b; Demidenko and Noiret, 2012b; Roussel et al., 2016; Demidenko and Haulk, 2017). In Western Europe, the ProtoAurignacian Layer VII of Grotte du Renne (Schmider, 2002) lies at $\sim 47.5^{\circ} \mathrm{N}$, while Beg ar $\mathrm{C}^{\prime}$ hastel ( $48.5^{\circ} \mathrm{N}$; Giot et al., 1975), and a possible Proto-Aurignacian component in the mixed assemblage from Spy Cave $\left(\sim 50.5^{\circ} \mathrm{N}\right.$; Flas et al., 2012) may suggest a more northerly 
limit. In Eastern Europe, the northernmost site described as Proto-Aurignacian is Chulek I $\left(\sim 48^{\circ} \mathrm{N}\right)$. At $\sim 51.5^{\circ} \mathrm{N}$, Kostenki is further north than any of these.

\section{Early Upper Paleolithic chronocultural succession at Kostenki and across Europe}

As discussed, our interpretation of the Kostenki 17/II assemblage as a local ProtoAurignacian variant is consistent with the fact that both apparently date to the same period. With regard more generally to Kostenki's early EUP retouched bladelet assemblages, our results strengthen the chronological and cultural separation of the Kostenki 17/II Spitsynian material from the younger, typically Early Aurignacian material found in Kostenki 14/LVA and Kostenki 1/III.

Our new radiocarbon dates of of 34.5-33 ka BP (39-37 ka cal BP) for the Aurignacian of Kostenki 14/LVA support an age close to (and possibly slightly younger than) the Campanian Ignimbrite/Y5 tephra (Table 6; Fig. 6). This is in good agreement with the age of other European Early Aurignacian assemblages (Higham et al., 2011; Teyssandier and Zilhão, 2018; SOM S1).

With regard to Kostenki 1/III, Hoffecker et al. (2016) have recently published radiocarbon dates of 32.5-29 ka BP for the layer, although they were (understandably) reluctant to explicitly relate individual dates to the site's Aurignacian occupation. The recent excavations at Kostenki 1 have confirmed that Layer III probably represents multiple occupations (Hoffecker et al., 2016), and some newly excavated material attributed to the layer is thought to be unrelated to the Aurignacian assemblage found previously in Layer III (Anikovich et al., 2008). Therefore, it is impossible to know whether Hoffecker et al.'s (2016) dated samples relate to Kostenki 1's Aurignacian occupation. Given the strong similarities between the lithic material from Kostenki 14/LVA and the Aurignacian material from Kostenki 1/III, we suggest that our new dates of 34.5-33 ka BP for the former (Table 6), corroborated by 
their association with the CI tephra, also provide the best available age estimate for Aurignacian material in Kostenki 1/III. This age would be consistent with the chronostratigraphic position of the Kostenki 1/III Aurignacian.

When considered together, the early EUP assemblages from Kostenki 1, Kostenki 14 and Kostenki 17 are therefore in good agreement—chronologically and in terms of the modified bladelets produced - with the archaeological record further west in Europe. Given the obvious problems with the radiocarbon chronology of Siuren I (Demidenko and Noiret, 2012a), an argument that Eastern European Aurignacian occupation represents a dispersal from Western Europe (Hoffecker et al., 2016) is difficult to sustain.

Furthermore, if it is accepted that the Spitsynian assemblage from Kostenki 17/II can be viewed as culturally linked to Proto-Aurignacian assemblages, then Kostenki can be added to the list of locations where material of this type stratigraphically underlies Early Aurignacian material (Banks et al., 2013b), with no inversions of this stratigraphic succession yet known. More broadly, if the chronology of the Proto-Aurignacian and Early Aurignacian of Banks et al. $(2013 \mathrm{a}, \mathrm{b})$ is accepted, then our results support the view that the direction and speed of spread of EUP cultural changes within Europe are unobservable at the current resolution and efficacy of our dating methods (e.g., Banks et al., 2013b; Teyssandier and Zilhão, 2018). More work will no doubt bring greater clarity. In the meantime we suggest that, where radiocarbon dates contradict prevailing models, then the competing hypotheses should be evaluated according to the plausibility of their anthropological implications (Teyssandier and Zilhão, 2018).

\section{Conclusions}

This study provides, for the first time, high-resolution and reliable radiocarbon chronologies for key EUP lithic assemblages from Kostenki 17 and Kostenki 14. The dates 
obtained are on samples from well-stratified areas of the sites and are consistent with their stratigraphic positions, including their relationships with the CI tephra, giving us confidence in the results.

Our results from Kostenki 17/II are evidence for AMH activity on the East European Plain by $36 \mathrm{ka}$ BP (41 ka cal BP), approximately contemporary with early AMH-associated Upper Paleolithic assemblages elsewhere in Europe. These results must therefore be incorporated into future models of the vector(s) of initial $\mathrm{AMH}$ dispersal into Europe, and provide an important counterpoint to prevailing models that are heavily focused on dispersal along the Danube or Mediterranean coast (Conard and Bolus, 2003; Mellars, 2006a,b; Hoffecker, 2009; Nigst et al., 2014; Benazzi et al., 2015; Chu, 2018). A potential earlier (Streletskian) AMH presence at Kostenki-Borshchevo is undemonstrated, due to the uncertainty of the Streletskian-AMH association and the inadequate connection between dated samples and diagnostic archaeological material at Kostenki's early Streletskian sites.

Our new study of Kostenki 17/II reveals important similarities with European ProtoAurignacian assemblages and related material in the Near East. Fully 'Upper Paleolithic' blade and bladelet production at the site followed unipolar strategies, with large, straightprofiled bladelets produced from burin-cores. The frequency of burin-cores in the assemblage indicates the overall importance of bladelet (rather than blade) production. Most significantly, the extant modified bladelet assemblage includes previously overlooked Dufour (Dufour subtype) bladelets. We therefore interpret the Spitsynian material from Kostenki $17 /$ II as a local variant of Proto-Aurignacian assemblages found further west. Our new radiocarbon dates of $\sim 36 \mathrm{ka}$ BP (40-41 ka cal BP) for Kostenki 17/II are consistent with this interpretation.

Lithic material from Kostenki 1/III and Kostenki 14/LVA is instead similar to Early Aurignacian assemblages from elsewhere in Europe. Our new radiocarbon dates for Kostenki 
14/LVA of 34.5-33 ka BP (39-37 ka cal BP), on samples found close to diagnostically Aurignacian bladelets, are in good agreement with the age of similar bladelet assemblages found further west in Europe.

These early EUP assemblages at Kostenki therefore fit well into the overall European chronocultural framework and are consistent with models of the EUP that predict penecontemporaneity of diagnostic assemblage types across large geographic areas.

Finally, our work highlights ongoing problems with the radiocarbon dating of certain Paleolithic sites. Well-stratified contexts were targeted for dating work, so that samples could confidently be related to the archaeological occupation under investigation and an established chronostratigraphic sequence could be used to corroborate results. Using standard collagen purification methods we obtained dates for Kostenki 14 that agreed well with the stratigraphic position of assemblages relative to the CI tephra. However, the same methods produced results for Kostenki $17 / \mathrm{II}$ that consistently underestimated the age of the samples, in two cases by around 10,000 (radiocarbon) years. Subsequent redating of samples using HYP pretreatment produced ages compatible with their position below the CI tephra, and in agreement with expectations based on the layer's archaeological contents.

Our work shows that for bones treated with consolidants it is important to use compoundspecific methods that exclude these types of contaminants. Our results may also indicate a problem with using standard radiocarbon dating techniques for some open-air sites, perhaps because bones are more likely to be exposed to exogenous soil humate contaminants in these contexts. Work to explore the influence of this continues. In the meantime, models that incorporate independent chronological markers, such as tephras, as well as regional and continental-scale archaeological and technotypological data, are key to the construction of robust chronological frameworks. 


\section{Acknowledgements}

This research was supported by the Leverhulme Trust (RPG-2012-800). A.B.'s work was supported by grants RFBR 18-39-20009 and RSF 18-78-00136, and by state assignment 0184-2018-0012. NR was supported during the writing of this paper by a Postdoctoral Study Grant from the Fondation Fyssen and the European Union's Horizon 2020 research and innovation programme under Marie Skłodowska-Curie grant agreement No 747400. A.S. acknowledges grant RFBR 17-06-00319a and state assignment 0184-2018-0012, and we also acknowledge the participation of ZIN RAS (state assignment AAAA-A17-117022810195-3). The research that enabled the production of HYP radiocarbon dates came from the European Research Council under the European Union's Seventh Framework Programme (FP7/20072013); ERC grant 324139 "PalaeoChron", which also supported N.R., T.D. and T.H. We acknowledge support from the UK Natural Environment Research Council (NERC) for the Oxford node of the national NERC Radiocarbon Facility, and gratefully acknowledge all staff of the ORAU, especially Dan Comeskey for his work on HYP pretreatment. Many thanks are due to the numerous friends and colleagues with whom we have discussed the Kostenki EUP and to several colleagues who kindly offered comments on an earlier draft of this paper, as well as to the reviewers for their helpful comments. We are very grateful to William Banks for discussions, and Maria Medvedeva and Natalia Lazarevskaya for their generous help with the IIMK RAN archive material.

\section{References}

Adler, D.S., BarOz, G., BelferCohen, A., BarYosef, O., 2006. Ahead of the game: Middle and Upper Palaeolithic hunting behaviors in the Southern Caucasus. Current Anthropology 47, 89-118. 
Adler, D.S., Bar-Yosef, O., Belfer-Cohen, A., Tushabramishvili, N., Boaretto, E., Mercier, N., Valladas, H., Rink, W.J., 2008. Dating the demise: Neandertal extinction and the establishment of modern humans in the southern Caucasus. Journal of Human Evolution $55,817-833$.

Alex, B., Barzilai, O., Hershkovitz, I., Marder, O., Berna, F., Caracuta, V., Abulafia, T., Davis, L., Goder-Goldberger, M., Lavi, R., Mintz, E., Regev, L., Mayer, D.B.-Y., Tejero, J.-M., Yeshurun, R., Ayalon, A., Bar-Matthews, M., Yasur, G., Frumkin, A., Latimer, B., Hans, M.G., Boaretto, E., 2017. Radiocarbon chronology of Manot Cave, Israel and Upper Paleolithic dispersals. Science Advances 3, e1701450.

Allsworth-Jones, P., 1986. The Szeletian and the Transition from Middle to Upper Palaeolithic in Central Europe. Oxford University Press, Oxford.

Allsworth-Jones, P., 1990. The Szeletian and the stratigraphic succession in central Europe and adjacent areas: main trends, recent results, and problems for resolution. In: Mellars, P. (Ed.), The Emergence of Modern Humans: An Archaeological Perspective. Cornell University Press, New York, pp. 160-242.

Anderson, L., Bon, F., Bordes, J.-G., Pasquini, A., Slimak, L., Teyssandier, N., 2015. Relier des espaces, construire de nouveaux réseaux: aux origines du Protoaurignacien et des débuts du Paléolithique supérieur en Europe occidentale. In: Naudinot, N., Meignen, L., Binder, D., Querré, G. (Eds.), Les Systèmes de Mobilité de La Préhistoire Au Moyen-Age. ADPCA, Antibes, pp. 93-109.

Anikovich, M.V., 1977. Pamiatniki streletskoi kul'tury v Kostenkakh. Ph.D. Dissertation, Institute for the History of Material Culture RAS (in Russian).

Anikovich, M.V., 1992. Kul'tura verkhnego paleolita tsentral'noi i vostochnoi Evropy. Arkheologicheskie Vesti 1, 188-191 (in Russian). 
Anikovich, M.V., 1999. The Formation of Upper Palaeolithic cultures and anatomically modern humans: the East European perspective. Anthropologie 37, 115-123.

Anikovich, M.V., 2000. Nachal'naia pora verkhnego paleolita vostochnoi Evropy. Stratum Plus 2000 , 11-30 (in Russian).

Anikovich, M.V., 2002. Proiskhozhdeniye kostenkovsko-streletskoy kul'tury i problema poiska kul'turno-geneticheskikh svyazey mezhdu srednim i verkhnim paleolitom. Stratum Plus 2000, 266-290 (in Russian).

Anikovich, M.V., Hoffecker, J.F., Popov, V.V., Kuz'mina, I.E., Levkovskaya, G.M., Pospelova, G.M., Forman, S., Holliday, V.T., 2004. Novye dannye o mnogosloinoi stoianke Kostenki 12 (Volkovskaia). In: Anikovich M.V., Platonova N.I. (Eds.), Kostenki i Ranniaia Pora Verkhnego Paleolita Evrazii: Obshchee i Lokal'noe. Istoki, Voronezh, pp. 18-38 (in Russian).

Anikovich, M.V., Sinitsyn, A.A., Hoffecker, J.F., Holliday, V.T., Popov, V.V., Lisitsyn, S.N., Forman, S.L., Levkovskaya, G.M., Pospelova, G.A., Kuz’mina, I.E., Burova, N.D., Goldberg, P., Macphail, R.I., Giaccio, B., Praslov, N.D., 2007. Early Upper Paleolithic in Eastern Europe and implications for the dispersal of modern humans. Science 315, 223226.

Anikovich, M.V., Popov, V.V., Platonova, N.I., 2008. Paleolit KostenkovskoBorshchevskogo Raiona v Kontekste Verkhnego Paleolita Evropy. Trudy KostenkovskoBorshchevskoi Arkheologocheskoi Ekspeditsii 1. Nestor-Istoriia, Saint Petersburg (in Russian).

Banks, W.E., d'Errico, F., Zilhão, J., 2013a. Human-climate interaction during the Early Upper Paleolithic: testing the hypothesis of an adaptive shift between the ProtoAurignacian and the Early Aurignacian. Journal of Human Evolution 64, 39-55. 
Banks, W.E., d'Errico, F., Zilhão, J., 2013b. Revisiting the chronology of the ProtoAurignacian and the Early Aurignacian in Europe: a reply to Higham et al.'s comments on Banks et al. (2013). Journal of Human Evolution 65, 810-817.

Bar-Yosef, O., Belfer-Cohen, A., Mesheviliani, T., Jakeli, N., Bar-Oz, G., Boaretto, E., Goldberg, P., Kvavadze, E., Matskevich, Z., 2011. Dzudzuana: an Upper Palaeolithic cave site in the Caucasus foothills (Georgia). Antiquity 85, 331-349.

Bataille, G., 2013. Der Übergang vom Mittel- zum Jungpaläolithikum auf der Halbinsel Krim und in der Kostenki-Borshchevo-Region am Mittel-Don. Adaptionsstrategien spätmittelpaläolithischer und früh-jungpaläolithischer Gruppen. Ph.D. Dissertation, University of Cologne.

Bataille, G., 2016. Extracting the "Proto" from the Aurignacian. Distinct production sequences of blades and ladelets in the Lower Aurignacian Phase of Siuren I, Units H and G (Crimea). Mitteilungen der Gesellschaft für Urgeschichte 25, 49-85.

Bataille, G., 2017. Neanderthals of Crimea - Creative generalists of the late Middle Paleolithic. Contextualizing the leaf point industry Buran-Kaya III, Level C. Quaternary International 435, 211-236.

Benazzi, S., Slon, V., Talamo, S., Negrino, F., Peresani, M., Bailey, S.E., Sawyer, S., Panetta, D., Vicino, G., Starnini, E., Mannino, M.A., Salvadori, P.A., Meyer, M., Pääbo, S., Hublin, J-J. 2015. The makers of the Protoaurignacian and implications for Neandertal extinction. Science 348, 793-796.

Benazzi, S., Douka, K., Fornai, C., Bauer, C.C., Kullmer, O., Svoboda, J., Pap, I., Mallegni, F., Bayle, P., Coquerelle, M., Condemi, S., Ronchitelli, A., Harvati, K., Weber, G.W., 2011. Early dispersal of modern humans in Europe and implications for Neanderthal behaviour. Nature 479, 525-528. 
Bergman, C.A., 1988. Ksar Akil and the Upper Palaeolithic of the Levant. Paléorient 14, $201-210$.

Bessudnov, A.A., 2008. Otchet o Rabote Spitsynskogo Otriada Kostenkovskoi Ekspeditsii IIMK RAN na Stoianke Kostenki 17 v 2008 godu. Unpublished report, Institute for the History of Material Culture, archive number RA IIMK RAN F. 35, op. 1. 2008. D. 17 (in Russian).

Bessudnov A.A., Dinnis R., Artyushenko A.A., 2018. Usloviia zaleganiia kul'turnykh gorizontov paleoliticheskoi stoianki Kostenki 17 (po rezul'tatam rabot 2017 g.). In: Bessudnov, A.A., Tkach, E.S. (Eds.), Aktual'naya Arkheologiya 4. Kompleksnye Issledovaniia v Arkheologii. Materialy Mezhdunarodnoi Nauchnoi Konferentsii Molodykh Uchenykh, Sankt-Peterburg, 2-5 Aprelia 2018. IIMK RAN, Saint Petersburg, pp. 69-73 (in Russian).

Bird, M.I., Levchenko, V., Ascough, P.L., Meredith, W., Wurster, C.M., Williams, A., Tilston, E.L., Snape, C.E., Apperley, D.C., 2014. The efficiency of charcoal decontamination for radiocarbon dating by three pre-treatments - ABOX, ABA and hypy. Quaternary Geochronology 22, 25-32.

Bon, F., 2002. L'Aurignacien Entre Mer et Océan. Réflexion sur l'Unité des Phases Anciennes de l'Aurignacien dans le Sud de la France. Société Préhistorique Française, Paris.

Bon, F., Bodu, P., 2002. Analyse technologique du débitage aurignacien. In: Schmider, B. (Ed.), L'Aurignacien de La Grotte Du Renne: Les Fouilles d'André Leroi-Gourhan à Arcy-Sur-Cure (Yonne), XXXIVe Supplément à Gallia Préhistoire. CNRS Éditions, Paris, pp. 115-133. 
Bordes, J.-G., 2005. La séquence aurignacienne du nord de l'Aquitaine: variabilité des productions lamellaires à Caminade-Est, Roc-de-Combe, le Piage et Corbiac-Vignoble II. In: Le Brun-Ricalens, F., Bordes, J.-G., Bon, F. (Eds.), Productions Lamellaires Attribuées à 1'Aurignacien: Chaînes Opératoires et Perspectives Technoculturelles, XIVe Congrès de l’UISPP, Liège, 2-8 Septembre 2001, ArchéoLogiques 1. Musée National d'Histoire et d'Art, Luxembourg, pp. 123-154.

Boriskovskii, P.I., 1963. Paleoliticheskaia stoianka Spitsyna (Kostenki XVII). Materialy i Issledovaniia po Arkheologii SSSR 121, 80-124 (in Russian).

Boriskovskii, P.I., Praslov, N.D., Anikovich, M.V., 1982. Kostenki 17 (Spitsynskaia stoianka). In: Praslov N.D., Rogachev A.N. (Eds.), Paleolit KostenkovskoBorshchevskogo Raiona na Donu, 1879-1979: Nekotorye Itogi Polevykh Issledovanii. Nauka, Leningrad, pp. 181-186 (in Russian).

Bosinski, G., 2013. Les précurseurs de l'art aurignacien. In: Bodu, P., Chehmana, L., Klaric, L., Mevel, L., Soriano, S., Teyssandier, N. (Eds.), Le Paléolithique Supérieur Ancien de l'Europe Du Nord-Ouest: Réflexions et Synthèses à Partir d'un Projet Collectif de Recherche Sur Le Centre et Le Sud Du Bassin Parisien (Actes Du Colloque de Sens, 1518 Avril 2009). Société Préhistorique Française, Paris, pp. 497-511.

Bourrillon, R., White, R., Tartar, E., Chiotti, L., Mensan, R., Clark, A., Castel, J.-C., Cretin, C., Higham, T., Morala, A., Ranlett, S., Sisk, M., Devièse, T., Comeskey, D.J., 2018. A new Aurignacian engraving from Abri Blanchard, France: Implications for understanding Aurignacian graphic expression in Western and Central Europe. Quaternary International 491, 46-64.

Bradley, B.A., Anikovich, M., Giria, E., 1995. Early Upper Palaeolithic in the Russian Plain: Streletskayan flaked stone artefacts and technology. Antiquity 69, 989-998. 
Brantingham, P.J., Kuhn, S.L., Kerry, K.W. (Eds.), 2004. The Early Upper Paleolithic beyond Western Europe. University of California Press, London.

Brock, F., Higham, T.F.G., 2009. AMS radiocarbon dating of Paleolithic-aged charcoal from Europe and the Mediterranean Rim using ABOx-SC. Radiocarbon 51, 839-846.

Brock, F., Higham, T., Ditchfield, P., Ramsey, C.B., 2010. Current pretreatment methods for AMS radiocarbon dating at the Oxford Radiocarbon Accelerator Unit (ORAU). Radiocarbon 52, 103-112.

Broglio, A., Bertola, S., Di Stefani, M., Marini, D., Lemorini, C., Rossetti, P., 2005. La production lamellaire et les armatures lamellaires de l'Aurignacien ancien de la grotte de Fumane (Monts Lessini, Vénétie). In: Le Brun-Ricalens, F., Bordes, J.-G., Bon, F. (Eds.), Productions Lamellaires Attribuées à l'Aurignacien: Chaînes Opératoires et Perspectives Technoculturelles, XIVe Congrès de l'UISPP, Liège, 2-8 Septembre 2001, ArchéoLogiques 1. Musée National d'Histoire et d'Art, Luxembourg, pp. 415-436.

Bronk Ramsey, C., 2009. Bayesian analysis of radiocarbon dates. Radiocarbon 51, 337-360.

Chabai, V., 2003. The chronological and industrial variability of the Middle to Upper Paleolithic transition in Eastern Europe. In: Zilhão, J., d'Errico, F. (Eds.), The Chronology of the Aurignacian and of the Transitional Technocomplexes. Dating, Stratigraphies, Cultural Implications. Instituto Portugues de Arquologia, Lisbon, pp. 71-86.

Chernysh, A.P., 1959. Pozdnii Paleolit Srednego Pridnestrov'ia. Trudy Komissii po Izucheniiu Chetvertichnogo Perioda 15. Nauka, Moscow (in Russian).

Chiotti, L., 2005. Les Industries Lithiques Aurignaciennes de l'Abri Pataud, Dordogne, France: Les fouilles de Hallam L. Movius Jr. British Archaeological Reports, Oxford.

Chiotti, L., Cretin, C., Morala, A., 2015. The lithic industries from Blanchard and Castanet rock shelters (Dordogne, France): data from the 2005-2012 excavations. In: White, R., 
Bourrillon, R. (Eds.), Aurignacian Genius: Art, Technology and Society of the First Modern Humans in Europe, Proceedings of the International Symposium, April 08-10 2013, New York University. P@lethnology 7, 76-97.

Chu, W., 2018. The Danube Corridor Hypothesis and the Carpathian Basin: geological, environmental and archaeological approaches to characterizing Aurignacian dynamics. Journal of World Prehistory 31, 117-178.

Cohen, V.Y., Stepanchuk, V.N., 1999. Late Middle and Early Upper Paleolithic evidence from the East European Plain and Caucasus: a new look at variability, interactions, and transitions. Journal of World Prehistory 13, 265-319.

Conard, N. J., Bolus, M., 2003. Radiocarbon dating the appearance of modern humans and timing of cultural innovations in Europe: New results and new challenges. Journal of Human Evolution 44, 331-371.

d'Errico, F., Banks, W.E., 2015. Tephra studies and the reconstruction of Middle-to-Upper Paleolithic cultural trajectories. Quaternary Science Reviews 118, 182-193.

Damblon, F., Haesaerts, P., van der Plicht, J., 1996. New datings and considerations on the chronology of Upper Palaeolithic sites in the Great Eurasiatic plain. Préhistoire Européenne 9, 177-231.

Davies, W., White, D., Lewis, M., Stringer, C., 2015. Evaluating the transitional mosaic: frameworks of change from Neanderthals to Homo sapiens in eastern Europe. Quaternary Science Reviews 118, 211-242.

Demars, P.-Y., Laurent, P., 1992. Types d'Outils Lithiques du Paléolithique Supérieur en Europe. CRNS, Paris. 
Demidenko, Y.E, 2004. Vostochnaia Evropa v kontekste problematiki orin'iaka Evropy: proshlye podkhody i novye perspektivy. Arkheologicheskiy Al'manakh 16, 161-194 (in Russian).

Demidenko, Y.E., 2009. East European Aurignacian and its Early/Archaic industry of KremsDufour type in the Great North Black Sea Region. Praehistoria 9-10, 149-182.

Demidenko, Y.E., 2012. Concluding considerations. In: Demidenko, Y.E., Otte, M., Noiret, P. (Eds.), Siuren I Rock-Shelter. From Late Middle Paleolithic and Early Upper Paleolithic to Epi-Paleolithic in Crimea. Éditions ERAUL, Liège, pp. 389-401.

Demidenko, Y.E., Haulk, T.C., 2017. Yabrud II rock-shelter archaeological sequence (Syria) and possible Proto- Aurignacian origin in the Levant. In: Wojtczak, D., Al Najjar, M., Jagher, R., Elsuede, H., Wegmüller, F., Otte, M. (Eds.), Vocation Préhistoire. Hommage à Jean-Marie Le Tensorer. Université de Liège, Liège, pp. 87-98.

Demidenko, Y.E., Noiret, P., 2012a. Radiocarbon dates for the Siuren I sequence. In: Demidenko, Y.E., Otte, M., Noiret, P. (Eds.), Siuren I Rock-Shelter. From Late Middle Paleolithic and Early Upper Paleolithic to Epi-Paleolithic in Crimea. Éditions ERAUL, Liège, pp. 49-53.

Demidenko, Y.E., Noiret, P., 2012b. The Siuren I Aurignacian of Krems-Dufour type industries in the context of the European Aurignacian. In: Demidenko, Y.E., Otte, M., Noiret, P. (Eds.), Siuren I Rock-Shelter. From Late Middle Paleolithic and Early Upper Paleolithic to Epi-Paleolithic in Crimea. Éditions ERAUL, Liège, pp. 343-357.

Devièse, T., Karavanić, I., Comeskey, D., Kubiak, C., Korlević, P., Hajdinjak, M., Radović, S., Procopio, N., Buckley, M., Pääbo, S., Higham, T., 2017. Direct dating of Neanderthal remains from the site of Vindija Cave and implications for the Middle to Upper Paleolithic transition. Proceedings of the National Academy of Sciences USA 114, 10606-10611. 
Devièse, T., Comeskey, D., McCullagh, J., Bronk Ramsey, C., Higham, T., 2018. New protocol for compound-specific radiocarbon analysis of archaeological bones. Rapid Communications in Mass Spectrometry 32, 373-379.

Dinnis, R., Flas, D., 2016. Trou du Renard and the Belgian Aurignacian. Proceedings of the Prehistoric Society 82, 1-25.

Dinnis, R., Reynolds, N., Bessudnov, A. A., Denisova, A. 2017. Some observations on platform preparation at Sungir'. Lithics 38, 18-26.

Dinnis, R., Bessudnov, A.A., Reynolds, N., Douka, K., Dudin, A.E., Khlopachev, G.A., Sablin, M.V., Sinitsyn, A.A., Higham, T.F.G., 2018. The age of the "AnosovkaTel'manskaya Culture" and the issue of a late Streletskian at Kostenki 11. Proceedings of the Prehistoric Society 84. https://doi.org/10.1017/ppr.2018.1

Douka, K., Higham, T., 2017. The chronological factor in understanding the Middle and Upper Paleolithic of Eurasia. Current Anthropology 58, S480-S490.

Douka, K., Higham, T., Sinitsyn, A., 2010. The influence of pretreatment chemistry on the radiocarbon dating of Campanian Ignimbrite-aged charcoal from Kostenki 14 (Russia). Quaternary Research 73, 583-587.

Falcucci, A., Conard, N.J., Peresani, M., 2017. A critical assessment of the Protoaurignacian lithic technology at Fumane Cave and its implications for the definition of the earliest Aurignacian. PLoS One 12, e0189241.

Falcucci, A., Peresani, M., Roussel, M., Normand, C., Soressi, M., 2018. What's the point? Retouched bladelet variability in the Protoaurignacian. Results from Fumane, Isturitz, and Les Cottés. Archaeological and Anthropological Sciences 10, 539-554.

Flas, D., Tartar, E., Bordes, J.-G., Le Brun-Ricalens, F., Zwyns, N., 2012. New perspectives on the Aurignacian from Spy: lithic assemblage, osseous artifacts and chrono-cultural 
sequence. In: Rougier, H., Semal, P. (Eds.), Spy Cave: 125 Years of Multidisciplinary Research at the Betche Aux Rotches (Jemeppe-Sur-Sambre, Province of Namur, Belgium), Volume 1. Anthropologica et Praehistorica 123, 231-255.

Gerasimova, M.M., Astakhov, S.N., Velichko, A.A., 2007. Paleoliticheskii Chelovek, ego Material'naya Kul'tura i Prirodnaya Sreda Obitaniya. Nestor-Istoriya, Saint Petersburg (in Russian).

Giaccio, B., Hajdas, I., Isaia, R., Deino, A., Nomade, S., 2017. High-precision ${ }^{14} \mathrm{C}$ and ${ }^{40} \mathrm{Ar} /{ }^{39} \mathrm{Ar}$ dating of the Campanian Ignimbrite (Y-5) reconciles the time-scales of climaticcultural processes at $40 \mathrm{ka}$. Scientific Reports 7, 45940.

Giot, P.-R., Talec, L., Monnier, J.L., Allard, M., 1975. Le Paléolithique supérieur du Pays de Léon (Finistère). L'Anthropologie 79, 39-79.

Giria, E.I., 1997. Tekhnologicheskii Analiz Kamennykh Industrii: Metodika MikroMakroanaliza Drevnykh Orudii Truda. Chast' 2. IIMK RAN, Saint Petersburg (in Russian).

Goebel, T., 2007. The missing years for modern humans. Science 315, 194-196.

Grigor'ev, G.P., 1968. Nachalo Verkhnego Paleolita i Proiskhozhdenie Homo sapiens. Nauka, Leningrad (in Russian).

Haesaerts, P., Damblon, F., van der Plicht, J., Otte, M., Nigst, P.R., 2017. Additional data to the stratigraphy and the chronology of the Kostenki 1 (Poliakov) sequence, Voronezh, Russia. In: Vasilyev, S.V., Sinitsyn, A., Otte, M. (Eds.), Le Sungirien. Éditions ERAUL, Liège, pp. 135-142.

Hahn, J., 1970. Recherches sur l'Aurignacien en Europe Centrale et Orientale. L'Anthropologie 74, 195-220. 
Higham, T.F.G. 2011. European Middle and Upper Palaeolithic radiocarbon dates are often older than they look: problems with previous dates and some remedies. Antiquity 85, 235249.

Higham, T.G., Jacobi, R.M., Ramsey, C.B., 2006. AMS radiocarbon dating of ancient bone using ultrafiltration. Radiocarbon 48, 179-195.

Higham, T., Brock, F., Peresani, M., Broglio, A., Wood, R., Douka, K., 2009. Problems with radiocarbon dating the Middle to Upper Palaeolithic transition in Italy. Quaternary Science Reviews 28, 1257-1267.

Higham, T., Jacobi, R., Basell, L., Ramsey, C.B., Chiotti, L., Nespoulet, R., 2011. Precision dating of the Palaeolithic: A new radiocarbon chronology for the Abri Pataud (France), a key Aurignacian sequence. Journal of Human Evolution 61, 549-563.

Higham, T., Basell, L., Jacobi, R., Wood, R., Ramsey, C.B., Conard, N.J., 2012. Testing models for the beginnings of the Aurignacian and the advent of figurative art and music: The radiocarbon chronology of Geißenklösterle. Journal of Human Evolution 62, 664676.

Higham, T., Wood, R., Moreau, L., Conard, N., Ramsey, C.B., 2013. Comments on "Humanclimate interaction during the early Upper Paleolithic: testing the hypothesis of an adaptive shift between the Proto-Aurignacian and the Early Aurignacian" by Banks et al. Journal of Human Evolution 65, 806-809.

Higham, T., Douka, K., Wood, R., Ramsey, C.B., Brock, F., Basell, L., Camps, M., Arrizabalaga, A., Baena, J., Barroso-Ruíz, C., Bergman, C., Boitard, C., Boscato, P., Caparrós, M., Conard, N.J., Draily, C., Froment, A., Galván, B., Gambassini, P., GarciaMoreno, A., Grimaldi, S., Haesaerts, P., Holt, B., Iriarte-Chiapusso, M.-J., Jelinek, A., Jordá Pardo, J.F., Maíllo-Fernández, J.-M., Marom, A., Maroto, J., Menéndez, M., Metz, 
L., Morin, E., Moroni, A., Negrino, F., Panagopoulou, E., Peresani, M., Pirson, S., de la Rasilla, M., Riel-Salvatore, J., Ronchitelli, A., Santamaria, D., Semal, P., Slimak, L., Soler, J., Soler, N., Villaluenga, A., Pinhasi, R., Jacobi, R., 2014. The timing and spatiotemporal patterning of Neanderthal disappearance. Nature 512, 306-309.

Hoffecker, J.F., 2009. The spread of modern humans in Europe. Proceedings of the National Academy of Sciences USA 106, 16040-16045.

Hoffecker, J.F., Holliday, V.T., 2014. Landscape archaeology and the dispersal of modern humans in Eastern Europe. In: Vasil'ev S.A., Tkach E.S. (Eds.), Verkhnii Paleolit Severnoi Evrazii i Ameriki: Pamiatniki, Kul'tury, Traditsii. Peterburgskoe Vostokovedenie, Saint Petersburg, pp. 140-170.

Hoffecker, J.F., Kuz'mina, I.E., Anikovich, M.V., Popov, V.V., 2005. Taphonomy of an early Upper Paleolithic bone bed at Kostenki 12 (Volkovskaya). In: M.V. Anikovich (Ed.), Problemy Rannei Pory Verkhnego Paleolita Kostenkovsko-Borshchevskogo Raiona i Sopredel'nykh Territorii. Trudy Kostenkovsko-Borshchevskoi Arkheologicheskoi Ekspeditsii 3. IIMK RAN, Saint Petersburg, pp. 161-176.

Hoffecker, J.F., Kuz'mina, I.E., Syromyatnikova, E.V., Anikovich, M.V., Sinitsyn, A.A., Popov, V.V., Holliday, V.T., 2010. Evidence for kill-butchery events of early Upper Paleolithic age at Kostenki, Russia. Journal of Archaeological Science 37, 1073-1089.

Hoffecker, J.F., Holliday, V.T., Anikovich, M.V., Dudin, A.E., Platonova, N.I., Popov, V.V., Levkovskaya, G.M., Kuz'mina, I.E., Syromyatnikova, E.V., Burova, N.D., Goldberg, P., Macphail, R.I., Forman, S.L., Carter, B.J., Crawford, L.J., 2016. Kostenki 1 and the early Upper Paleolithic of Eastern Europe. Journal of Archaeological Science: Reports 5, 307326. 
Holliday, V.T., Hoffecker, J.F., Goldberg, P., Macphail, R.I., Forman, S.L., Anikovich, M., Sinitsyn, A., 2007. Geoarchaeology of the Kostenki-Borshchevo sites, Don River Valley, Russia. Geoarchaeology 22, 181-228.

Hublin, J.-J., 2015. The modern human colonization of western Eurasia: when and where? Quaternary Science Reviews 118, 194-210.

Jacobi, R.M., Higham, T.F.G., Bronk Ramsey, C., 2006. AMS radiocarbon dating of Middle and Upper Palaeolithic bone in the British Isles: improved reliability using ultrafiltration. Journal of Quaternary Science 21, 557-573.

Jöris, O., Neugebauer-Maresch, C., Weninger, B., Street, M., 2010. The radiocarbon chronology of the Aurignacian to Mid-Upper Palaeolithic transition along the Upper and Middle Danube. In: Neugebauer-Maresch, C., Owen, L.R. (Eds.), New Aspects of the Central and Eastern European Upper Palaeolithic - Methods, Chronology, Technology and Subsistence. Symposium by the Prehistoric Commission of the Austrian Academy of Sciences, Vienna, November 9-11, 2005. Mitteilungen der Prähistorischen Kommission 72, 101-137.

Jöris, O., Street, M., 2008. At the end of the ${ }^{14} \mathrm{C}$ time scale - the Middle to Upper Paleolithic record of western Eurasia. Journal of Human Evolution 55, 782-802

Jöris, O., Street, M., Terberger, T., Weninger, B., 2011. Radiocarbon dating the Middle to Upper Palaeolithic transition: The demise of the last Neanderthals and the first appearance of anatomically modern humans in Europe. In: Condemi, S., Weniger, G.-C. (Eds.), Continuity and Discontinuity in the Peopling of Europe: One Hundred Fifty Years of Neanderthal Study. Springer, Dordrecht, pp. 239-298. 
Kadowaki, S., Omori, T., Nishiaki, Y., 2015. Variability in Early Ahmarian lithic technology and its implications for the model of a Levantine origin of the Protoaurignacian. Journal of Human Evolution 82, 67-87.

Klaric, L., Lev, S., Giria, Y., Polanská, M., 2015. Couteaux de Kostienki et lames aménagées par technique de Kostienki - Retour sur un malentendu historique. Bulletin de la Société Préhistorique Française 112, 421-474.

Kozłowski, J.K., 1986. The Gravettian in Central and Eastern Europe. In: Wendorf, F., Close, A.E. (Eds.), Advances in World Archaeology, Vol. 5. Academic Press, Orlando, pp. 131200.

Kozłowski, J.K., 2014. Europe: Early Upper Paleolithic. In: Smith, C. (Ed.), Encyclopedia of Global Archaeology. Springer Science and Business Media, New York, pp. 2570-2580.

Kozłowski, J.K., Otte, M., 2000. La formation de l'Aurignacien en Europe. L'Anthropologie $104,3-15$.

Lazukov, G.I., 1957. Geologiia stoianok Kostenkovsko-Borshevskogo raiona. Materialy i Issledovaniia po Arkheologii SSSR 59, 135-173 (in Russian).

Lazukov, G. I., 1982. Kharakteristika chetvertichnykh otlozhenii raiona. In: Praslov, N.D., Rogachev, A.N. (Eds.), Paleolit Kostenkovsko-Borshchevskogo Raiona na Donu, 18791979: Nekotorye Itogi Polevykh Issledovanii. Nauka, Leningrad, pp. 13-37 (in Russian).

Le Brun-Ricalens, F., Bordes, J.-G., Bon, F. (Eds.), 2005. Productions Lamellaires Attribuées à l'Aurignacien: Chaînes Opératoires et Perspectives Technoculturelles. XIVe Congrès de l’UISPP, Liège, 2-8 Septembre 2001, ArchéoLogiques 1. Musée National d'Histoire et d'Art, Luxembourg.

Levkovskaya, G.M., Shumilovskikh, L.S., Anikovich, M.V., Platonova, N.I., Hoffecker, J.F., Lisitsyn, S.N., Pospelova, G.A., Kuzmina, I.E., Sanko, A.F., 2015. Supra-regional 
correlations of the most ancient paleosols and Paleolithic layers of Kostenki-Borschevo region (Russian Plain). Quaternary International, 365, 114-134.

Marks, A.E., Monigal, K., 2000. The Middle to Upper Paleolithic interface at Buran-KayaIII, Eastern Crimea. In: Orschiedt, J., Weniger, G.-C. (Eds.), Neanderthals and Modern Humans - Discussing the Transition: Central and Eastern Europe from 50,000-30,000 BP. Neanderthal Museum, Mettmann, pp. 212-226.

Marom, A., McCullagh, J.S.O., Higham, T.F.G., Sinitsyn, A.A., Hedges, R.E.M., 2012. Single amino acid radiocarbon dating of Upper Paleolithic modern humans. Proceedings of the National Academy of Sciences USA 109, 6878-6881.

Mellars, P., 2006a. A new radiocarbon revolution and the dispersal of modern humans in Eurasia. Nature 439, 931-935.

Mellars, P., 2006b. Archeology and the dispersal of modern humans in Europe: Deconstructing the "Aurignacian”. Evolutionary Anthropology 15, 167-182.

Mester, Z., 2014. Le Szélétien. In: Otte, M. (Ed.), Neandertal/Cro-Magnon. La Rencontre. Éditions Errance, Paris, pp. 149-188.

Michel, A., 2010. L'Aurignacien récent (post-ancien) dans le Sud-Ouest de la France: variabilité des productions lithiques. Révision taphonomiques et techno-économiques des sites de Caminade-Est, abri Pataud, Roc-de-Combe, Le Flageolet I, La Ferrassie et Combemenue. Ph.D. Dissertation, Université Bordeaux I.

Monigal, K., Usik, V., Koulakovskaya, L., Gerasimenko, N.P., 2006. The beginning of the Upper Paleolithic in Transcarpathia, Ukraine. Anthropologie 44, 61-74.

Moreau, L., Odar, B., Higham, T., Horvat, A., Pirkmajer, D., Turk, P., 2015. Reassessing the Aurignacian of Slovenia: techno-economic behaviour and direct dating of osseous projectile points. Journal of Human Evolution 78, 158-180. 
Müller, U.C., Pross, J., Tzedakis, P.C., Gamble, C., Kotthoff, U., Schmiedl, G., Wulf, S., Christanis, K., 2011. The role of climate in the spread of modern humans into Europe. Quaternary Science Reviews 30, 273-279.

Nalawade-Chavan, S., McCullagh, J., Hedges, R., 2014. New hydroxyproline radiocarbon dates from Sungir, Russia, confirm early Mid Upper Palaeolithic burials in Eurasia. PLoS One 9, e76896.

Nigst, P.R., Haesaerts, P., Damblon, F., Frank-Fellner, C., Mallol, C., Viola, B., Götzinger, M., Niven, L., Trnka, G., Hublin, J.-J., 2014. Early modern human settlement of Europe north of the Alps occurred 43,500 years ago in a cold steppe-type environment. Proceedings of the National Academy of Sciences USA 111, 14394-14399.

Noiret, P., 2013. De quoi Gravettien est-il le nom? In: Otte, M. (Ed.), Les Gravettiens. Éditions Errance, Paris, pp. 29-64.

Normand, C., O'Farrell, M., Rios Garaizar, J., 2009. The function(s) of Archaic Aurignacian bladelets: data and thoughts based on examples from Isturitz Cave (Pyrénées-Atlantiques, France). In: Pétillon, J.-M., Dias-Meirinho, M.-H., Cattelain, P., Honegger, M., Normand, C., Valdeyron, N. (Eds.), Projectile Weapon Elements from the Upper Palaeolithic to the Neolithic. P@lethnology 1, 6-44.

O’Farrell, M., 2005. Éude préliminaire des éléments d'armature lithique de l'Aurignacien ancien de Brassempouy. In: Le Brun-Ricalens, F., Bordes, J.-G., Bon, F. (Eds.), Productions Lamellaires Attribuées à l'Aurignacien: Chaînes Opératoires et Perspectives Technoculturelles, XIVe Congrès de l'UISPP, Liège, 2-8 Septembre 2001, ArchéoLogiques 1. Musée National d'Histoire et d'Art, Luxembourg, pp. 395-412. 
Otte, M., 2014. Europe: Middle to Upper Paleolithic transition. In: Smith, C. (Ed.), Encyclopedia of Global Archaeology. Springer Science and Business Media, New York, pp. 2586-2591.

Ovchinnikov, I.V., Götherström, A., Romanova, G.P., Kharitonov, V.M., Lidén, K., Goodwin, W., 2000. Molecular analysis of Neanderthal DNA from the northern Caucasus. Nature 404, 490-493.

Pelegrin, J., 2000. Les techniques de débitage laminaire au Tardiglaciare: critères de diagnose et quelques réflexions. In: Valentin, B., Bodu, P., Christensen, M. (Eds.), L'Europe Centrale et Septentrionale Au Tardiglaciaire. Actes de La Table-Ronde Internationale de Nemours, 14-16 Mai 1997. Éditions APRAIF, Nemours, pp. 73-86.

Pelegrin, J., 2012. Sur les débitages laminaires du Paléolithique supérieur. In: Delpech, F., Jaubert, J. (Eds.), François Bordes et La Préhistoire: Colloque International François Bordes, Bordeaux, 22-24 Avril 2009. Comité des Travaux Historiques et Scientifiques, Paris, pp. 141-152.

Pelegrin, J., O’Farrell, M., 2005. Les lamelles retouchées ou utilisées de Castanet. In: Le Brun-Ricalens, F., Bordes, J.-G., Bon, F. (Eds.), Productions Lamellaires Attribuées à l'Aurignacien: Chaînes Opératoires et Perspectives Technoculturelles, XIVe Congrès de l’UISPP, Liège, 2-8 Septembre 2001, ArchéoLogiques 1. Musée National d'Histoire et d'Art, Luxembourg, pp. 103-121.

Perpère, M., Schmider, B., 2002. L'outillage lithique. In: Schmider, B. (Ed.), L'Aurignacien de La Grotte Du Renne: Les Fouilles d'André Leroi-Gourhan à Arcy-Sur-Cure (Yonne). CNRS, Paris, pp. 143-195. 
Pinhasi, R., Higham, T.F.G., Golovanova, L.V., Doronichev, V.B., 2011. Revised age of late Neanderthal occupation and the end of the Middle Paleolithic in the northern Caucasus. Proceedings of the National Academy of Sciences USA 108, 8611-8616.

Porraz, G., Simon, P., Pasquini, A., 2010. Identité technique et comportements économiques des groupes proto-aurignaciens à la grotte de l'Observatoire (principauté de Monaco). Gallia Préhistoire 52, 33-59.

Praslov, N.D., Rogachev, A.N., 1982. Paleolit Kostenkovsko-Borshchevskogo Raiona na Donu, 1879-1979: Nekotorye Itogi Polevykh Issledovanii. Nauka, Leningrad (in Russian).

Praslov, N.D., Rogachev, A.N., Kudryashov, V.E., 1980. Otchet o Rabotakh Kostenkovskoi Paleoliticheskoi Ekspeditsii v 1980 g. Unpublished report, Institute for the History of Material Culture, archive number RA IIMK RAN F. 35, op. 1. 1980. D. 46 (in Russian).

Pyle, D., Ricketts, G., Margari, V., van Andel, T., Sinitsyn, A., Praslov, N., Lisitsyn, S., 2006. Wide dispersal and deposition of distal tephra during the Pleistocene 'Campanian Ignimbrite/Y5' eruption, Italy. Quaternary Science Reviews 25, 2713-2728.

Reimer, P.J., Bard, E., Bayliss, A., Beck, J.W., Blackwell, P.G., Ramsey, C.B., Buck, C.E., Cheng, H., Edwards, R.L., Friedrich, M., Grootes, P.M., Guilderson, T.P., Haflidason, H., Hajdas, I., Hatté, C., Heaton, T.J., Hoffmann, D.L., Hogg, A.G., Hughen, K.A., Kaiser, K.F., Kromer, B., Manning, S.W., Niu, M., Reimer, R.W., Richards, D.A., Scott, E.M., Southon, J.R., Staff, R.A., Turney, C.S.M., van der Plicht, J., 2013. IntCal13 and Marine13 radiocarbon age calibration curves $0-50,000$ years cal BP. Radiocarbon 55, $1869-1887$.

Reynolds, N., Lisitsyn, S.N., Sablin, M.V., Barton, N., Higham, T., 2015. Chronology of the European Russian Gravettian: new radiocarbon dating results and interpretation. Quartär $62,121-132$. 
Reynolds, N., Dinnis, R., Bessudnov, A.A., Devièse, T., Higham, T., 2017. The Kostënki 18 child burial and the cultural and funerary landscape of Mid Upper Palaeolithic European Russia. Antiquity 91, 1435-1450.

Rogachev, A.N., 1957. Mnogosloynye stoianki Kostenkovsko-Borshevskogo raiona. Materialy i Issledovaniya po Arkheologii SSSR 59, 10-134 (in Russian).

Rogachev, A.N., 1963. Otchet o Rabote Kostenkovskogo Otriada LOIA AN SSSR v 1963 godu. Unpublished report, Institute for the History of Material Culture, archive number RA IIMK RAN F. 35. Op. 1. 1963. D. 9 (in Russian).

Rogachev, A.N., Anikovich, M.V., 1982. Kostenki 12 (Volkovskaya stoianka). In: Praslov N.D., Rogachev A.N. (Eds.), Paleolit Kostenkovsko-Borshchevskogo Raiona na Donu, 1879-1979: Nekotorye Itogi Polevykh Issledovanii. Nauka, Leningrad, pp. 132-140 (in Russian).

Roussel, M., Soressi, M., Hublin, J.-J., 2016. The Châtelperronian conundrum: Blade and bladelet lithic technologies from Quinçay, France. Journal of Human Evolution 95, 13-32.

Schmider, B. (Ed.), 2002. L'Aurignacien de la Grotte du Renne: Les fouilles d'André LeroiGourhan à Arcy-sur-Cure (Yonne). CNRS, Paris.

Schmidt, C., Sitlivy, V., Anghelinu, M., Chabai, V., Kels, H., Uthmeier, T., Hauck, T., Baltean, I., Hilgers, A., Richter, J., Radtke, U., 2013. First chronometric dates (TL and OSL) for the Aurignacian open-air site of Româneşti-Dumbrăviţa I, Romania. Journal of Archaeological Science 40, 3740-3753.

Sedov, S.N., Khokhlova, O.S., Sinitsyn, A.A., Korkka, M.A., Rusakov, A.V., Ortega, B., Solleiro, E., Rozanova, M.S., Kuznetsova, A.M., Kazdym, A.A., 2010. Late Pleistocene paleosol sequences as an instrument for the local paleographic reconstruction of the 
Kostenki 14 key section (Voronezh Oblast) as an example. Eurasian Soil Science 43, 876892.

Shchelinskii, V.E., 2007. Paleolit Chernomorskogo Poberezh'ia Severo-Zapadnogo Kavkaza (Pamiatniki Otkrytogo Tipa). Evropeiskii Dom, Saint Petersburg (in Russian).

Sikora, M., Seguin-Orlando, A., Sousa, V.C., Albrechtsen, A., Korneliussen, T., Ko, A., Rasmussen, S., Dupanloup, I., Nigst, P.R., Bosch, M.D., Renaud, G., Allentoft, M.E., Margaryan, A., Vasilyev, S.V., Veselovskaya, E.V., Borutskaya, S.B., Devièse, T., Comeskey, D., Higham, T., Manica, A., Foley, R., Meltzer, D.J., Nielsen, R., Excoffier, L., Lahr, M.M., Orlando, L., Willerslev, E., 2017. Ancient genomes show social and reproductive behavior of early Upper Paleolithic foragers. Science 358, 659-662.

Sinitsyn, A.A., 1993. Les niveaux aurignaciens de Kostienki I. In: Bánesz, L., Kozłowski, J.K. (Eds.), Aurignacien en Europe et au Proche-Orient. Actes du XIIème Congrès International des Sciences Préhistoriques et Protohistoriques, Bratislava, 1-7 Septembre 1991. Institut Archéologique de l'Académie Slovaque des Sciences, Nitra-Bratislava, pp. $242-259$.

Sinitsyn, A.A., 1996. Kostenki 14 (Markina gora): Data, problems, and perspectives. Préhistoire Européenne 9, 273-313.

Sinitsyn, A.A., 1997. Inventar' vtorogo kul'turnogo sloia Tel'manskoi stoianki i problema proiskhozhdeniia "vostochnogo gravetta". In: T.A. Popova (Ed.), Razvitiye Kul'tury v Kamennom Veke. Kratkoe Soderzhanie Dokladov na Mezhdunarodnoi Konferentsii, Posviashchennoi 100-Letiiu Otdela Arkheologii MAE. MAE RAN, Saint Petersburg, pp. 61-63 (in Russian).

Sinitsyn, A.A., 2003. A Palaeolithic 'Pompeii’ at Kostenki, Russia. Antiquity 77, 9-14. 
Sinitsyn, A.A., 2010. The Early Upper Palaeolithic of Kostenki: chronology, taxonomy, and cultural affiliation. In: Neugebauer-Maresch, C., Owen, L.R. (Eds.), New Aspects of the Central and Eastern European Upper Palaeolithic - Methods, Chronology, Technology and Subsistence. Symposium by the Prehistoric Commission of the Austrian Academy of Sciences; Vienna, November 9-11, 2005. Mitteilungen der Prähistorischen Kommission $72,27-48$.

Sinitsyn, A.A., 2014. L'Europe Orientale. In: Otte, M. (Ed.), Neandertal/Cro-Magnon. La Rencontre. Éditions Errance, Paris, pp. 189-220.

Sinitsyn, A.A., 2016a. Kostenki 14 (Markina gora). In: Sapelkin, N.S. (Ed.), Guidebook of the International Theoretical and Practical Conference «Multidisciplinary Methods in the Study and Preservation of Sites in the Kostenki-Borshchevo Archaeological Area» (Voronezh, 15-17 Sept. 2016). Tsentral'no-Chernozemnoye Knizhnoye Izdatel'stvo, Voronezh, pp. 15-19.

Sinitsyn, A.A., 2016b. Kostenki 14 (Markina gora). In: Chalykh, N.E. (Ed.), Arkheologicheskiye Issledovaniya v Tsentral'nom Chernozem'ye 2015. Novyi Vzgliad, Lipetsk, pp. 66-69 (in Russian).

Sinitsyn, A.A., Hoffecker, J.F., 2006. Radiocarbon dating and chronology of the Early Upper Paleolithic at Kostenki. Quaternary International, 152-153, 164-174.

Sinitsyn, A.A., Praslov, N.D., Svezhentsev, Y.S., Sulerzhitskiy, L.D., 1997. Radiouglerodnaia khronologiia verkhnego paleolita vostochnoi Evropy. In: Sinitsyn, A.A., Praslov, N.D. (Eds.), Radiouglerodnaia Khronologiia Paleolita Vostochnoi Evropy i Severnoi Azii: Problemy i Perspektivy. AkademPrint, Saint Petersburg, pp. 21-66 (in Russian). 
Sirakov, N., Tsanova, T., Sirakova, S., Taneva, S., Krumov, I., Dimitrova, I., Kovatcheva, N., 2007. Un nouveau faciés lamellaire du début du Paléolithique supérieur dans les Balkans. Paléo 19, 131-144.

Škrdla, P., 2014. Moravian Bohunician. In: Otte, M. (Ed.), Neandertal/Cro-Magnon. La Rencontre. Éditions Errance, Paris, pp. 123-147.

Škrdla, P., Rychtaříková, T., 2012. Levallois point or blade: which blank was the target artefact of the Bohunician technology? In: Pastoors, A., Peresani, M. (Eds.), Flakes Not Blades: The Role of Flake Production at the Onset of the Upper Palaeolithic in Europe. Neanderthal Museum, Mettmann, pp. 199-214.

Slimak, L., Svendsen, J.I., Mangerud, J., Plisson, H., Heggen, H.P., Brugère, A., Pavlov, P.Y., 2011. Late Mousterian persistence near the Arctic Circle. Science 332, 841-845.

Stuiver, M., Polach, H.A., 1977. Discussion: Reporting of C-14 data. Radiocarbon 19, 355363.

Svezhentsev, Y.S., Popov, S.G., 1993. Late Paleolithic chronology of the East European Plain. Radiocarbon 35, 495-501.

Tafelmaier, Y., 2017. Technological Variability at the Beginning of the Aurignacian in Northern Spain. Implications for the Proto- and Early Aurignacian Distinction. Neanderthal Museum, Mettmann.

Teyssandier, N., Zilhão, J., 2018. On the entity and antiquity of the Aurignacian at Willendorf (Austria): implications for modern human emergence in Europe. Journal of Paleolithic Archaeology 1, 107-138.

Tsanova, T., Zwyns, N., Eizenberg, L., Teyssandier, N., Le Brun-Ricalens, F., Otte, M., 2012. Le plus petit dénominateur commun: réflexion sur la variabilité des ensembles 
lamellaires du Paléolithique supérieur ancien d'Eurasie. Un bilan autour des exemples de Kozarnika (Est des Balkans) et Yafteh (Zagros central). L'Anthropologie 116, 469-509.

Usik, V.I., 2008. Verkhnii paleolit Zakarpat'ia: khronologiia i kul'turnaia prinadlezhnost' orin'iaka Beregovo I. Materialy i Doslidzhennya z Arkheolohiyi Prykarpattya i Volyni 12, 49-67 (in Russian).

Usik, V., Monigal, K., Kulakovskaya, L., 2006. New perspectives on the Transcarpathian Middle to Upper Paleolithic boundary. In: Conard, N.J. (Ed.), When Neanderthals and Modern Humans Met. Kerns Verlag, Tübingen, pp. 213-232.

Usik, V, Koulakovska, L, Nigst, P.R., Haesaerts, P., 2013. Doslidzhennya paleolitu Zakarpattya. In: Kozak D.N. (Ed.), Arkheologichni Doslidzhennya v Ukraini 2012. Institut Arkheologii National'noi Akademii Nauk Ukraini, Kiev-Lutsk, pp. 173-174 (in Ukrainian).

Velichko, A.A., 1963. Stoianka Spitsyna (Kostenki XVII) i ee znachenie dlia resheniia osnovnykh voprosov geologii Kostenkovsko-Borshevskogo raiona. Materialy i Issledovaniia po Arkheologii SSSR 121, 201-219 (in Russian).

Velichko, A.A., Pisareva, V.V., Sedov, S.N., Sinitsyn, A.A., Timireva, S.N., 2009. Paleogeography of Kostenki 14 (Markina gora). Archaeology, Ethnology \& Anthropology of Eurasia 37, 25-50.

Vereshchagin, N.K., Kuz'mina, I.E., 1977. Ostatki mlekopitaiushchikh iz paleoliticheskikh stoianok na Donu i verkhnei Desne. Trudy Zoologicheskogo Instituta AN SSSR 72, 77 110 (in Russian).

Vishnyatsky, L.B., 2016. Smena naseleniia v Evrope na rubezhe srednego i verkhnego paleolita i problema kul'turnoi preemstvennosti. Stratum Plus 2016, 17-28 (in Russian). 
Vishnyatsky, L.B., Nehoroshev, P.E., 2004. The beginning of the Upper Paleolithic on the Russian Plain. In: Brantingham, P.J., Kuhn, S.L., Kerry, K.W. (Eds.), The Early Upper Paleolithic beyond Western Europe. University of California Press, London, pp. 80-96.

White, R., Mensan, R., Bourrillon, R., Cretin, C., Higham, T.F.G., Clark, A.E., Sisk, M.L., Tartar, E., Gardère, P., Goldberg, P., Pelegrin, J., Valladas, H., Tisnérat-Laborde, N., Sanoit, J. de, Chambellan, D., Chiotti, L., 2012. Context and dating of Aurignacian vulvar representations from Abri Castanet, France. Proceedings of the National Academy of Sciences USA 109, 8450-8455.

Williams, J., Bergman, C.A., 2010. Upper Paleolithic levels XIII-VI (A and B) from the 1937-1938 and 1947-1948 Boston College excavations and the Levantine Aurignacian at Ksar Akil, Lebanon. Paléorient 36, 117-161.

Wood, R., 2015. From revolution to convention: the past, present and future of radiocarbon dating. Journal of Archaeological Science 56, 61-72.

Wood R.E, Douka K., Boscato P., Haesaerts P., Sinitsyn A., Higham T.F.G. 2012. Testing the ABOx-SC method: Dating known-age charcoals associated with the Campanian Ignimbrite. Quaternary Geochronology 9, 16-26.

Wood, R.E., Arrizabalaga, A., Camps, M., Fallon, S., Iriarte-Chiapusso, M.-J., Jones, R., Maroto, J., de la Rasilla, M., Santamaría, D., Soler, J., Soler, N., Villaluenga, A.,Higham, T.F.G. 2014. The chronology of the earliest Upper Palaeolithic in northern Iberia: New insights from L'Arbreda, Labeko Koba and La Viña. Journal of Human Evolution 69, 91109

Yurgenson, G.A., Giria, E.I., Moroz, P.V., 2012. Kremnevye syr'e Kostenok i kremni Russkoi ravniny (opyt sravneniia). Stratum Plus 2012, 179-191 (in Russian). 
Zilhão, J., 2011. Aliens from Outer Time? Why the "Human Revolution" is wrong, and where do we go from here? In: Condemi, S., Weniger, G.-C. (Eds.), Continuity and Discontinuity in the Peopling of Europe: One Hundred Fifty Years of Neanderthal Study. Springer, Dordrecht, pp. 331-366.

Zilhão, J., 2013. Neandertal-modern human contact in Western Eurasia: issues of dating, taxonomy, and cultural associations. In: Akazawa, T., Nishiaki, Y., Aoki, K. (Eds.), Dynamics of Learning in Neanderthals and Modern Humans: Volume 1, Cultural Perspectives. Springer, Tokyo, pp. 21-57.

Zilhão, J., d'Errico, F., 2003. The chronology of the Aurignacian and transitional technocomplexes. Where do we stand? In: Zilhão, J., d'Errico, F. (Eds.), The Chronology of the Aurignacian and of the Transitional Technocomplexes: Dating, Stratigraphies, Cultural Implications. Instituto Portugues de Arquologia, Lisbon, pp. 313-349.

Zilhão, J., Banks, W.E., d'Errico, F., Gioia, P., 2015. Analysis of site formation and assemblage integrity does not support attribution of the Uluzzian to modern humans at Grotta del Cavallo. PLoS One 10, e0131181.

Zwyns, N., Roebroeks, W., McPherron, S.P., Jagich, A., Hublin, J.-J., 2012. Comment on "Late Mousterian persistence near the Arctic Circle". Science 335, 167. 


\section{Table 1}

Boriskovskii's (1963) typological counts for lithic material from his 1953 and 1955 excavation of

Kostenki 17/II. Boriskovskii's 'special' burin category refers to "burins with a working edge made by a combination of abrupt retouch on the distal edge and a series of thin vertical burin spalls"

(Boriskovskii, 1963: 94; translation by A.B.). Note the two artifacts described as (atypical) Kostenki knives do not meet the revised technotypological criteria proposed for this artifact type (Klaric et al., 2015).

\begin{tabular}{lc}
\hline Type & Count \\
\hline End-scrapers & 22 \\
Burins: & 160 \\
$\quad$ angle burins & 4 \\
$\quad$ dihedral burins & 10 \\
$\quad$ 'special' type & 30 \\
$\quad$ burins on truncation & $>100$ \\
Burin spalls & $\sim 600$ \\
Splintered pieces & 9 \\
'Transitional' type between splintered pieces and flat-faceted burins & 15 \\
Kostenki knives (atypical) & 2 \\
Points & 18 \\
'Large' blades & 11 \\
Retouched blades and blade fragments & 4800 \\
Blades and their fragments & 4500 \\
Prismatic cores (+ fragments) & 110 \\
Hammer-stones & 200 \\
\hline Flakes & $15(+30)$ \\
\hline
\end{tabular}




\section{Table 2}

Previously published radiocarbon dates for Kostenki 17/II

\begin{tabular}{llll}
\hline Lab code & Sample & Result BP & Reference \\
\hline LE-1436 & Bone & $32,780 \pm 300$ & Svezhentsev and Popov, 1993; Sinitsyn et al., 1997 \\
GrN-10512 & Charcoal & $32,200 \pm 2000 / 1600$ & Svezhentsev and Popov, 1993; Sinitsyn et al., 1997 \\
GrN-12596 & Charcoal & $36,780 \pm 1700 / 1400$ & Svezhentsev and Popov, 1993; Sinitsyn et al., 1997
\end{tabular}

\section{Table 3}

Previously published radiocarbon dates for Kostenki 14/LVA.

\begin{tabular}{llll}
\hline Lab code & Sample & Result BP & Reference \\
\hline GrA-18230 & Bone & $20,640 \pm 170 / 160$ & Sinitsyn and Hoffecker, 2006 \\
GrA-18053 & Charcoal & $32,420 \pm 440 / 420$ & Sinitsyn and Hoffecker, 2006 \\
OxA-19134 & Shell & $29,134 \pm 140$ & Sinitsyn, 2014 \\
OxA-19787 & Charcoal & $33,220 \pm 220$ & Douka et al., 2010 \\
OxA-19021 a & Charcoal & $35,080 \pm 240$ & Douka et al., 2010 \\
OxA-26313 & Bone & $33,300 \pm 300$ & Douka and Higham, 2017 \\
OxA-26314 & Bone & $33,600 \pm 300$ & Douka and Higham, 2017 \\
OxA-X-2642-8 & Bone & $35,210 \pm 400$ & Douka and Higham, 2017
\end{tabular}

${ }^{a}$ Same sample as OxA-19787 using alternative pretreatment. 


\section{Table 4}

New radiocarbon dates for Kostenki 17/II. The dates were calibrated against the IntCal13 curve using OxCal version 4.2 (Reimer et al., 2013 ; Bronk Ramsey, 2017). Technical details related to the sample pretreatment can be found in SOM Table S2. No other radiocarbon dates (or failed dates) were produced for this context in the course of this work.

\begin{tabular}{|c|c|c|c|c|c|c|c|c|c|}
\hline $\begin{array}{l}\text { Sample } \\
\text { reference }\end{array}$ & Material & Species & $\begin{array}{l}\text { Museum } \\
\text { accession } \\
\text { ref }\end{array}$ & $\begin{array}{l}\text { Excavation } \\
\text { info }\end{array}$ & $\begin{array}{l}\text { Pretreatment } \\
\text { code }^{\mathrm{a}}\end{array}$ & Result $\pm 1 \sigma \mathrm{SD}$ & $\mathrm{Cal} \mathrm{BP} \pm 1 \sigma \mathrm{SD}$ & $\mathrm{Cal} \mathrm{BP} \pm 2 \sigma \mathrm{SD}$ & Lab code \\
\hline K2014/1 & Tooth & $\begin{array}{l}\text { Vulpes } \\
\text { lagopus }\end{array}$ & - & г101, 19 & $\mathrm{AF}^{*}$ & $26,830 \pm 250 \mathrm{BP}$ & $31,130-30,810$ & $31,280-30,630$ & OxA-30824 \\
\hline $\mathrm{K} 2014 / 2$ & Tooth & $\begin{array}{l}\text { Vulpes } \\
\text { lagopus }\end{array}$ & - & 65,20 & $\mathrm{AF}^{*}$ & $25,480 \pm 220 \mathrm{BP}$ & $29,910-29,250$ & $30,300-29,010$ & OxA-30825 \\
\hline K17-01 & Bone & $\begin{array}{l}\text { Canis } \\
\text { lupus }\end{array}$ & 28468 & - & $\mathrm{AF}^{*}$ & $32,350 \pm 450 \mathrm{BP}$ & $36,850-35,690$ & $37,800-35,280$ & OxA-32594 \\
\hline K17-01 & Bone & $\begin{array}{l}\text { Canis } \\
\text { lupus }\end{array}$ & 28468 & - & HYP & $35,650 \pm 690 \mathrm{BP}$ & $41,060-39,570$ & $41,640-38,860$ & OxA-X-2677-56 \\
\hline
\end{tabular}




\begin{tabular}{|c|c|c|c|c|c|c|c|c|c|}
\hline K17-02 & Bone & $\begin{array}{l}\text { Canis } \\
\text { lupus }\end{array}$ & 28468 & - & $\mathrm{AF}^{*}$ & $31,250 \pm 400 \mathrm{BP}$ & $35,560-34,760$ & $36,060-34,460$ & OxA-32595 \\
\hline K17-03 & Bone & $\begin{array}{l}\text { Canis } \\
\text { lupus }\end{array}$ & 28468 & - & $\mathrm{AF}^{*}$ & $33,050 \pm 500 \mathrm{BP}$ & $37,920-36,510$ & $38,540-36,100$ & OxA-32596 \\
\hline K17-03 & Bone & $\begin{array}{l}\text { Canis } \\
\text { lupus }\end{array}$ & 28468 & - & HYP & $36,020 \pm 740 \mathrm{BP}$ & $41,400-39,930$ & $42,000-39,160$ & OxA-X-2677-5 \\
\hline $\begin{array}{l}\text { K2014/1 } \\
+\end{array}$ & Tooth & $\begin{array}{l}\text { Vulpes } \\
\text { lagopus }\end{array}$ & N/A & N/A & HYP & $35,840 \pm 520 \mathrm{BP}$ & $41,070-39,930$ & $41,570-39,380$ & OxA-X-2717- \\
\hline
\end{tabular}

K2014/2

${ }^{\mathrm{a}}$ Pretreatment code: $\mathrm{AF}=$ ultrafiltered collagen (an asterisk denotes samples that have been solvent washed prior to the AF treatment); HYP = extraction of hydroxyproline from hydrolyzed bone collagen (Brock et al., 2010; Devièse et al., 2018). CRA is conventional radiocarbon age, expressed in years BP (Stuiver and Polach, 1977). 


\section{Table 5}

New radiocarbon dates for Kostenki 14/IVw. Technical details related to the sample pretreatment can be found in SOM Table S3. See caption of Table 4 for details of the terms used. No other radiocarbon dates (or failed dates) were produced for this context in the course of this work.

\begin{tabular}{|c|c|c|c|c|c|c|c|c|}
\hline $\begin{array}{l}\text { Sample } \\
\text { reference }\end{array}$ & Material & Species & Excavation info & $\begin{array}{l}\text { Pretreatment } \\
\text { code }\end{array}$ & Result $\pm 1 \sigma \mathrm{SD}$ & $\mathrm{Cal} \mathrm{BP} \pm 1 \sigma \mathrm{SD}$ & $\mathrm{Cal} \mathrm{BP} \pm 2 \sigma \mathrm{SD}$ & Lab code \\
\hline K14-03 & Bone & Lepus sp. & П-34 н/у -250 & $\mathrm{AF}$ & $35,800 \pm 700 \mathrm{BP}$ & $41,200-39,730$ & $41,780-38,990$ & OxA-33981 \\
\hline K14-04 & Bone & Lepus sp. & П-37 яма, н/у -258 & $\mathrm{AF}$ & $36,350 \pm 750 \mathrm{BP}$ & $41,660-40,260$ & $42,250-39,510$ & OxA-33982 \\
\hline K14-05 & Bone & Lepus sp. & P-33 -247 & $\mathrm{AF}$ & $35,750 \pm 700 \mathrm{BP}$ & $41,150-39,680$ & $41,740-38,940$ & OxA-33983 \\
\hline
\end{tabular}




\section{Table 6}

New radiocarbon dates for Kostenki 14/LVA. Technical details related to the sample pretreatment can be found in SOM Table S4. See caption of Table 4 for details of the terms used. No other radiocarbon dates (or failed dates) were produced for this context in the course of this work.

\begin{tabular}{|c|c|c|c|c|c|c|c|c|}
\hline $\begin{array}{l}\text { Sample } \\
\text { reference }\end{array}$ & Material & Species & Excavation info & $\begin{array}{l}\text { Pretreatment } \\
\text { code }\end{array}$ & Result $\pm 1 \sigma \mathrm{SD}$ & $\mathrm{Cal} \mathrm{BP} \pm 1 \sigma \mathrm{SD}$ & $\mathrm{Cal} \mathrm{BP} \pm 2 \sigma \mathrm{SD}$ & Lab code \\
\hline K14-11 & Bone & Equus ferus & $\begin{array}{l}\text { К-14-2000 М-74 (- } \\
\text { 204) Г.П. }\end{array}$ & $\mathrm{AF}^{*}$ & $34,400 \pm 600 \mathrm{BP}$ & $39,700-38,330$ & $40,450-37,340$ & OxA-35311 \\
\hline K14-12 & Bone & Equus ferus & К14-ГП-03 М-Н76 & $\mathrm{AF}^{*}$ & $34,400 \pm 550 \mathrm{BP}$ & $39,610-38,380$ & $40,330-37,540$ & OxA-35312 \\
\hline K14-13 & Bone & Equus ferus & К14-ГП-03 М77 & $\mathrm{AF}^{*}$ & $33,400 \pm 500 \mathrm{BP}$ & $38,370-36,980$ & $38,830-36,350$ & OxA-35313 \\
\hline K14-14 & Bone & Equus ferus & $\begin{array}{l}\text { К14-03-ГП М-76 } \\
\text { (-196) вне зольной } \\
\text { линзы }\end{array}$ & $\mathrm{AF}^{*}$ & $33,150 \pm 500 \mathrm{BP}$ & $38,070-36,660$ & $38,610-36,190$ & OxA-35314 \\
\hline
\end{tabular}




\section{Table 7}

Platform type for detachment of burin spalls for 138 burins (32 double) in the studied Kostenki 17/II assemblage.

\begin{tabular}{lr}
\hline Platform & Count \\
\hline Break & 20 \\
Burin spall & 9 \\
Truncation & 136 \\
Unmodified edge & 2 \\
Indet. & 3 \\
Total & 170 \\
\hline
\end{tabular}

\section{Table 8}

Truncation type for truncation burin removal platforms in the studied Kostenki 17/II assemblage.

\begin{tabular}{ll}
\hline Truncation type & Count \\
\hline Slightly concave & 6 \\
Indet. & 2 \\
Lateral & 10 \\
Concave & 37 \\
Oblique & 76 \\
End-scraper front & 3 \\
Straight & 2 \\
Total & 136 \\
\hline
\end{tabular}


Table 9

The six modified bladelets from Kostenki 17/II (see Fig. 7).

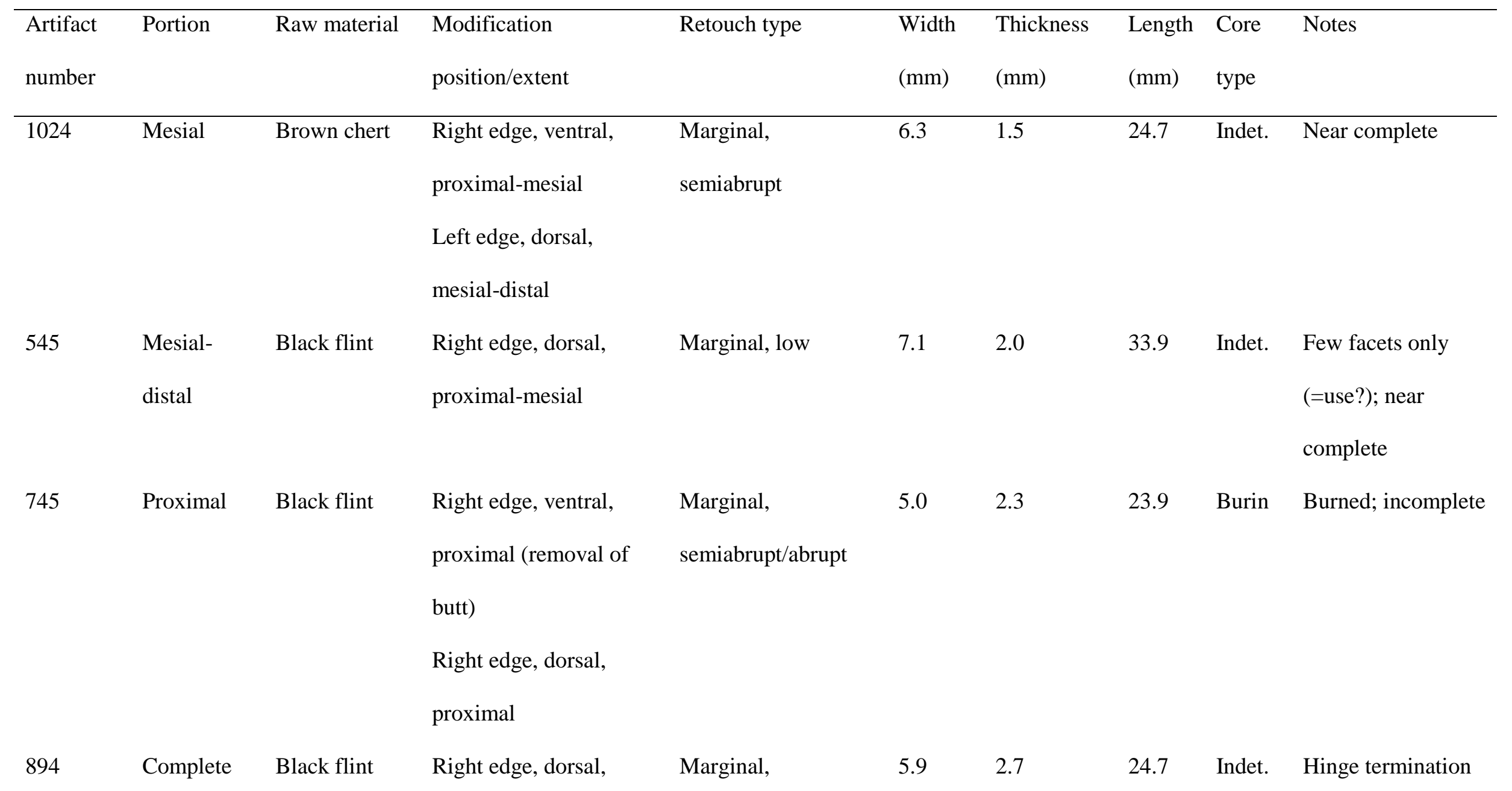




\begin{tabular}{|c|c|c|c|c|c|c|c|c|}
\hline & & proximal & semiabrupt & & & & & \\
\hline \multirow[t]{2}{*}{ Complete } & Black flint & Left edge, dorsal, & Marginal, & 5.8 & 1.8 & 25.1 & Burin & Small distal \\
\hline & & proximal-mesial & semiabrupt & & & & & burination \\
\hline Proximal- & Indet. & Right edge, ventral, & Marginal, & 7.7 & 3.1 & 25.2 & Indet. & Tip broken; near \\
\hline \multirow[t]{2}{*}{ Mesial } & (heavily & entire edge & semiabrupt & & & & & complete \\
\hline & patinated) & Left edge, dorsal, & & & & & & \\
\hline
\end{tabular}




\section{Table 10}

Metrics for the Kostenki 17/II bladelets (Table 9) and retouched bladelets from the Proto-Aurignacian of Les Cottés and Isturitz (France) and Fumane (Italy); data from Falcucci et al. (2018).

\begin{tabular}{|c|c|c|}
\hline & Site & Mean (mm) \\
\hline \multirow[t]{4}{*}{ Length } & Fumane $(n=85)$ & 26.6 \\
\hline & Isturitz $(n=15)$ & 25.1 \\
\hline & Les Cottés $(n=2)$ & 26.7 \\
\hline & Kostenki 17/II $(n=5)$ & 26.7 \\
\hline \multirow[t]{4}{*}{ Width } & Fumane $(n=1751)$ & 6.5 \\
\hline & Isturitz $(n=963)$ & 5.3 \\
\hline & Les Cottés $(n=150)$ & 6.8 \\
\hline & Kostenki 17/II $(n=6)$ & 6.3 \\
\hline \multirow[t]{4}{*}{ Thickness } & Fumane $(n=1751)$ & 1.7 \\
\hline & Isturitz $(n=963)$ & 1.5 \\
\hline & Les Cottés $(n=150)$ & 1.9 \\
\hline & Kostenki 17/II $(n=6)$ & 2.2 \\
\hline
\end{tabular}

